\title{
REVIEW
}

Open Access

\section{Polyphenols-loaded electrospun nanofibers in bone tissue engineering and regeneration}

Iruthayapandi Selestin Raja ${ }^{1 \dagger}$, Desingh Raj Preeth ${ }^{2 \dagger}$, Mohan Vedhanayagam³ ${ }^{3}$ Suong-Hyu Hyon ${ }^{4}$, Dohyung Lim ${ }^{5}$, Bongju Kim ${ }^{6 *}$, Subramaniyam Rajalakshmi ${ }^{2^{*}}$ and Dong-Wook Han ${ }^{1,7^{*}}$ (D)

\begin{abstract}
Bone is a complex structure with unique cellular and molecular process in its formation. Bone tissue regeneration is a well-organized and routine process at the cellular and molecular level in humans through the activation of biochemical pathways and protein expression. Though many forms of biomaterials have been applied for bone tissue regeneration, electrospun nanofibrous scaffolds have attracted more attention among researchers with their physicochemical properties such as tensile strength, porosity, and biocompatibility. When drugs, antibiotics, or functional nanoparticles are taken as additives to the nanofiber, its efficacy towards the application gets increased. Polyphenol is a versatile green/phytochemical small molecule playing a vital role in several biomedical applications, including bone tissue regeneration. When polyphenols are incorporated as additives to the nanofibrous scaffold, their combined properties enhance cell attachment, proliferation, and differentiation in bone tissue defect. The present review describes bone biology encompassing the composition and function of bone tissue cells and exemplifies the series of biological processes associated with bone tissue regeneration. We have highlighted the molecular mechanism of bioactive polyphenols involved in bone tissue regeneration and specified the advantage of electrospun nanofiber as a wound healing scaffold. As the polyphenols contribute to wound healing with their antioxidant and antimicrobial properties, we have compiled a list of polyphenols studied, thus far, for bone tissue regeneration along with their in vitro and in vivo experimental biological results and salient observations. Finally, we have elaborated on the importance of polyphenol-loaded electrospun nanofiber in bone tissue regeneration and discussed the possible challenges and future directions in this field.
\end{abstract}

Keywords: Bone tissue regeneration, Electrospun nanofiber, Polyphenols, Drug loading

\footnotetext{
*Correspondence: bjkim016@gmail.com; rajimaniyam@gmail.com; nanohan@pusan.ac.kr

+Iruthayapandi Selestin Raja and Desingh Raj Preeth contributed equally to this work.

${ }^{6}$ Dental Life Science Research Institute / Innovation Research \& Support Center for Dental Science, Seoul National University Dental Hospital, Seoul 03080, South Korea

${ }^{2}$ Chemical Biology and Nanobiotechnology Laboratory, AU-KBC Research Centre, Anna University, MIT Campus, Chromepet, Chennai 600 044, India 'BIO-IT Fusion Technology Research Institute, Pusan National University, Busan 46241, South Korea

Full list of author information is available at the end of the article
}

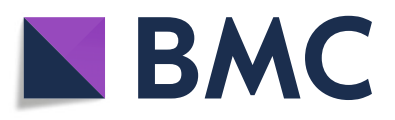

(c) The Author(s). 2021 Open Access This article is licensed under a Creative Commons Attribution 4.0 International License, which permits use, sharing, adaptation, distribution and reproduction in any medium or format, as long as you give appropriate credit to the original author(s) and the source, provide a link to the Creative Commons licence, and indicate if changes were made. The images or other third party material in this article are included in the article's Creative Commons licence, unless indicated otherwise in a credit line to the material. If material is not included in the article's Creative Commons licence and your intended use is not permitted by statutory regulation or exceeds the permitted use, you will need to obtain permission directly from the copyright holder. To view a copy of this licence, visit http://creativecommons.org/licenses/by/4.0/. The Creative Commons Public Domain Dedication waiver (http://creativecommons.org/publicdomain/zero/1.0/) applies to the data made available in this article, unless otherwise stated in a credit line to the data. 


\section{Background}

Plant polyphenols are excellent sources of natural antioxidants and antimicrobials, acting as potential drugs in modern biomedicine $[1,2]$. Tissue regeneration and remodeling is one of the tedious and complex processes in bone tissue regeneration. Polyphenols have been promising bioactive micronutrients to safeguard and maintain bone health [3-5]. Plenty of research works have been reported to study the intriguing effects of polyphenols, likely antimicrobial, antioxidant and anti-inflammatory activity playing a vital role in bone tissue engineering [6-8]. The polyphenols' action to maintain the balance is attributed to their hydroxyl substituents' hydrogen bond donating ability [9]. Maintaining redox equilibrium is a critical factor in tissue engineering during the angiogenesis process, an essential step to promote long-term survival and engraftment of bone. Polyphenols can be classified into four major groups, flavonoids, lignans, stilbenes, and phenolic acids depending on the number of reactive phenolic units [10]. The flavones and catechins are the most potent flavonoids to protect the body from the reactive oxygen species (ROS) [11]. The mechanisms of polyphenols' antioxidant action include (1) scavenging ROS, (2) up-regulation or protection of antioxidant defenses, and (3) suppression of ROS formation either by inhibition of enzymes or by chelating trace elements involved in the free radical generation [12]. Several polyphenolic compounds such as curcumin, quercetin, catechin, icariin, EGCG, and resveratrol have been studied to apply bone tissue engineering. They initiate upregulation of several biochemical pathways by scavenging free radicals and mediate the expression of inflammatory cytokines involved in bone tissue remodeling, as shown in Fig. $1[14,15]$. Characteristic inhibition of nuclear factor kappa-B (NF-kB), cyclooxygenase-2 (COX-2), protein-lysine 6-oxidase (LOX), and inducible nitric oxide synthase (iNOS) and activation of activating protein-1 (AP-1), mitogen-activated protein kinase (MAPK), protein kinase $\mathrm{C}$ (PKC), nuclear factorerythroid 2-related factor 2 (Nrf2), and phase II antioxidant detoxifying enzymes are affiliated to the antiinflammatory activities of the polyphenols [16].

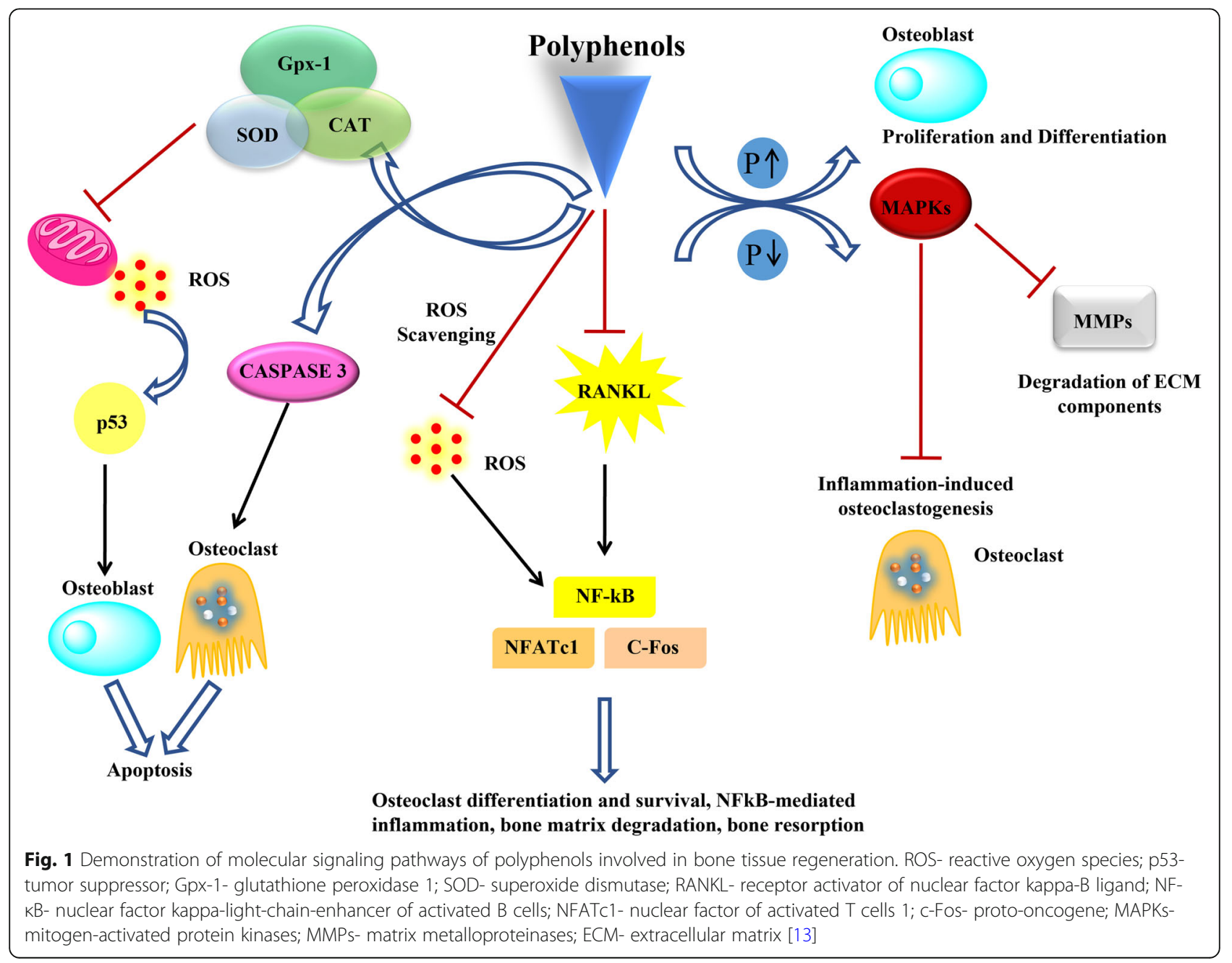


Polyphenols demarcate the inflammatory responses, control the osteoclast's activation process, and activate the osteoblast's production through various signaling proteins such as RANKL, osteoprotegerin (OPG), etc. [17].

An ideal scaffold for the guided bone regeneration should be biocompatible, space-making, and permeable to fluids but acting as barriers for cells, slowly resorbable, bone-promoting, coupled with exceptional biological properties including antimicrobial ability, and commercially inexpensive [18-21]. The scaffold with these properties can be achieved in the electrospun nanofibrous membrane of the biomaterials [22-25]. During the last two decades, many researchers have shown increasing interest in the fabrication of nanofibers for bone tissue engineering applications. They develop nanofibers through multiple techniques such as electrospinning (conventional or coaxial) [26], self-assembly [27], vapor phase polymerization [28], and phase separation [29].
Among these methods, the electrospinning method is a versatile technique, which has been widely utilized to fabricate nano-fibrous scaffolds with nanosized pores and fiber diameter. The electrospun nanofibers thus prepared closely imitate extracellular matrix (ECM) with suitable mechanical property, porosity, and surface-areato-volume ratio, which supports enhanced cell adhesion, spreading, growth, and proliferation [30]. The functional electrospun scaffold can be produced by incorporating desired biomolecules and nanoparticles into the polymeric solution (Fig. 2). The porosity and fiber diameter of electrospun fibers can be tuned by altering the parameters such as voltage, needle to collector distance, injection rate, roller speed, etc. [32]. Core-shell nanofibers are generated using a specialized coaxial electrospinning method, which uses two aligned needles that can concurrently spin two different polymer solutions [33].

The advantage of electrospun nanofibers as a drug carrier is that a greater number of drugs can be

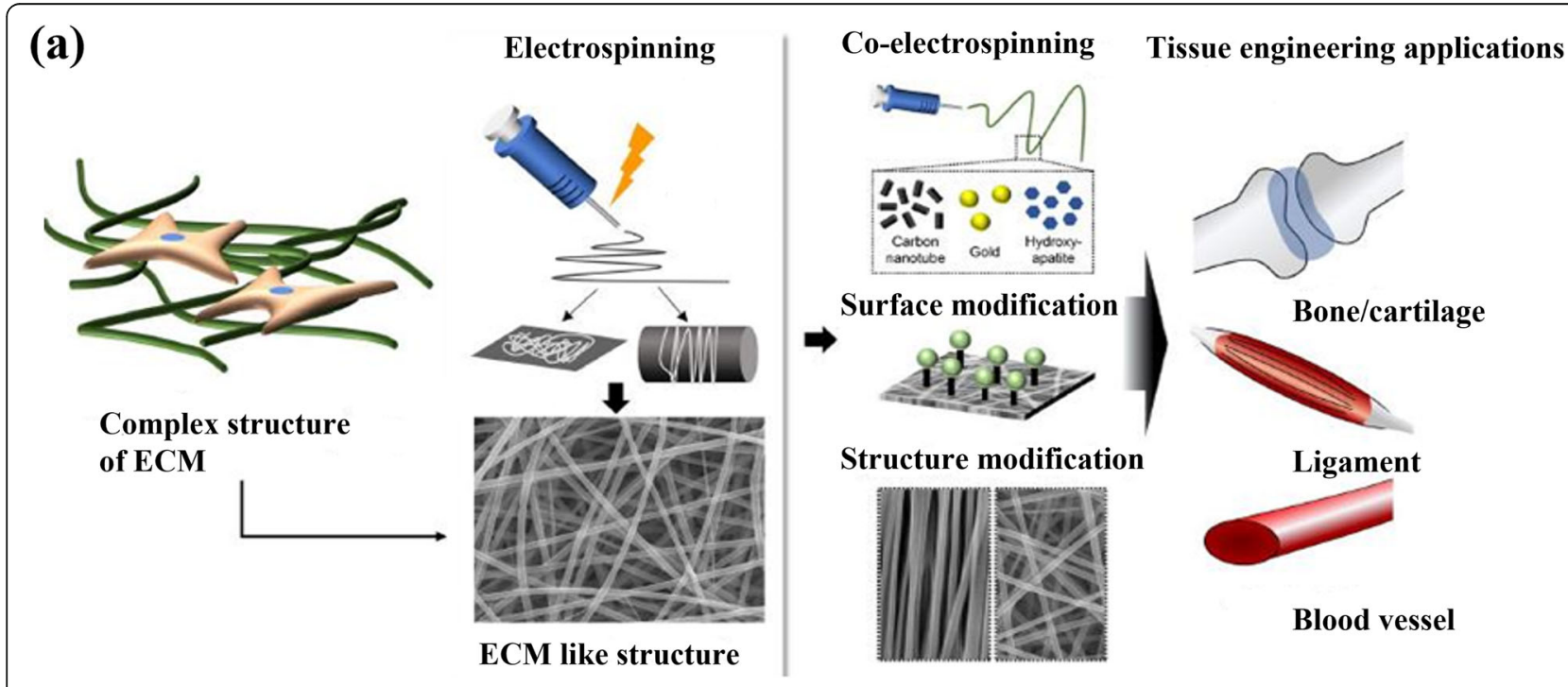

(b)

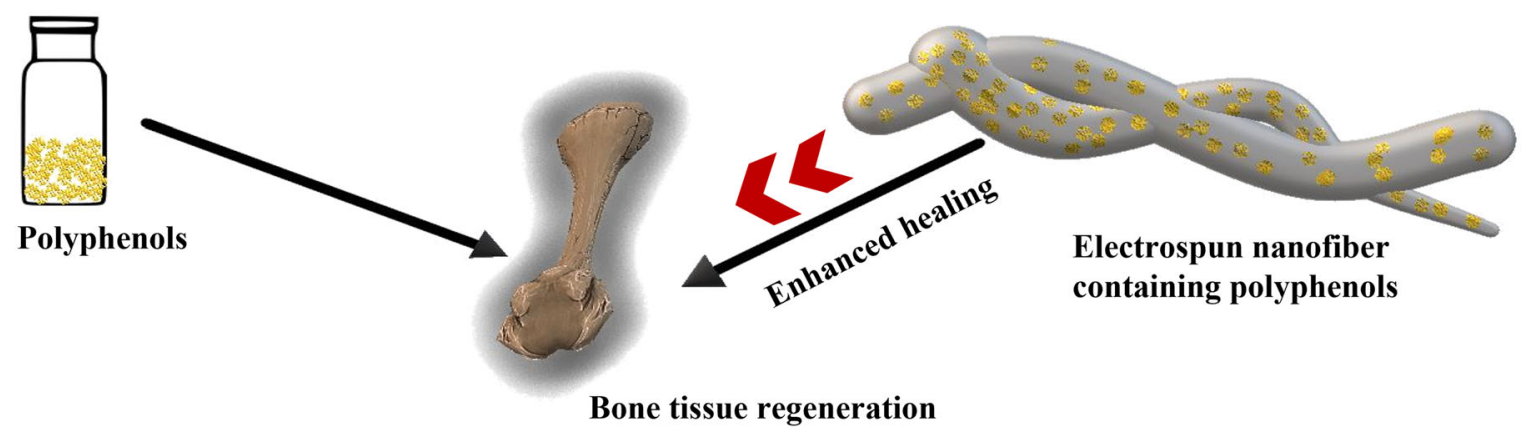

Fig. 2 Electrospun nanofibers imitating extracellular matrix (ECM). a Major types of electrospinning and post-modification of electrospun nanofibers for the application of bone tissue engineering are demonstrated [31]. b Though polyphenols alone can help bone tissue regeneration, electrospun nanofiber containing polyphenols shows enhanced wound healing due to the sustained release of bioactive molecules from the scaffold 
encapsulated into the scaffold compared to other forms of nanocarriers such as micelles, nanoparticles, hydrogels, etc. [29]. Further, the nanofibers can demonstrate a sustained drug release preserving the bioavailability of active drugs like polyphenols [4, 34], antibiotics [35], oligopeptides [36], medicative ingredients [37], and growth factors [38]. Various drug loading strategies lead to different kinds of interaction between drugs and nanofibers, observing different drug-releasing kinetics [39]. A curcumin-loaded $\mathrm{PCL} /$ gum tragacanth electrospun nanofiber was demonstrated to improve the bioavailability of curcumin, heal the wound faster, and enhance fibroblast proliferation and collagen deposition [40]. A core-shell electrospun nanofiber of PVA and PLGA loaded with naringin and metronidazole improved nanofibers' antibacterial action, cell mobility, proliferation, and mineralization in dental application [41]. A biodegradable electrospun scaffold incorporated with transforming growth factor $\beta-3$ improved stiffness of the nanofiber and modulated chondrogenesis, and increased collagen I protein expression [42].

Bone is a prominent exoskeletal framework safeguarding the vital organs inside the body. The complex cellular architecture of the bone comprised 35\% of organic and $65 \%$ of inorganic materials and can be classified into micro and nanocomposite tissues [43-47]. A series of biological processes, bone resorption, and bone formation make up the skeletal system, in which four major cells are involved in maintaining multiple extracellular and intracellular signaling networks (Fig. 3). Among the cells, osteoclasts and osteoblasts are responsible for bone resorption and the formation of bone matrix, respectively. These cell structures can withstand the physical pressure and maintain phosphocalcic homeostasis [49, 50]. Another cell type formed from the maturate phase of osteoblast is the osteocyte, which acts as a sensor for the endocrine responses [51]. The bone resorption and formation could be integrated using the bone cell lining, called osteogenic cells.

Bone tissue regeneration is the critical process to maintain the bone mass by repairing and regeneration. For years, $25 \%$ of trabecular bone and 3\% of cortical bone have been removed and replaced through the bone regeneration process in human beings [52]. Inflammation, renewal, and bone remodeling are the three interconnecting phases involved in the bone tissue regeneration process. The inflammatory phase begins within $24 \mathrm{~h}$ of bone fracture or damage and continues up to a week. The blood flows into the damaged site leading to coagulation and inflammation as the immediate response after the fracture [53]. At this juncture, a series of complex signals such as proinflammatory signals and growth factors are released in a spatially controlled way [54]. Several inflammatory mediators, including interleukin-1 (IL-1, IL-6, IL-11, and IL-18) and tumor necrosis factor- $\alpha$, are significantly elevated, leading to angiogenesis through inflammatory cells [55]. The platelets are activated by the damaged blood vessels to

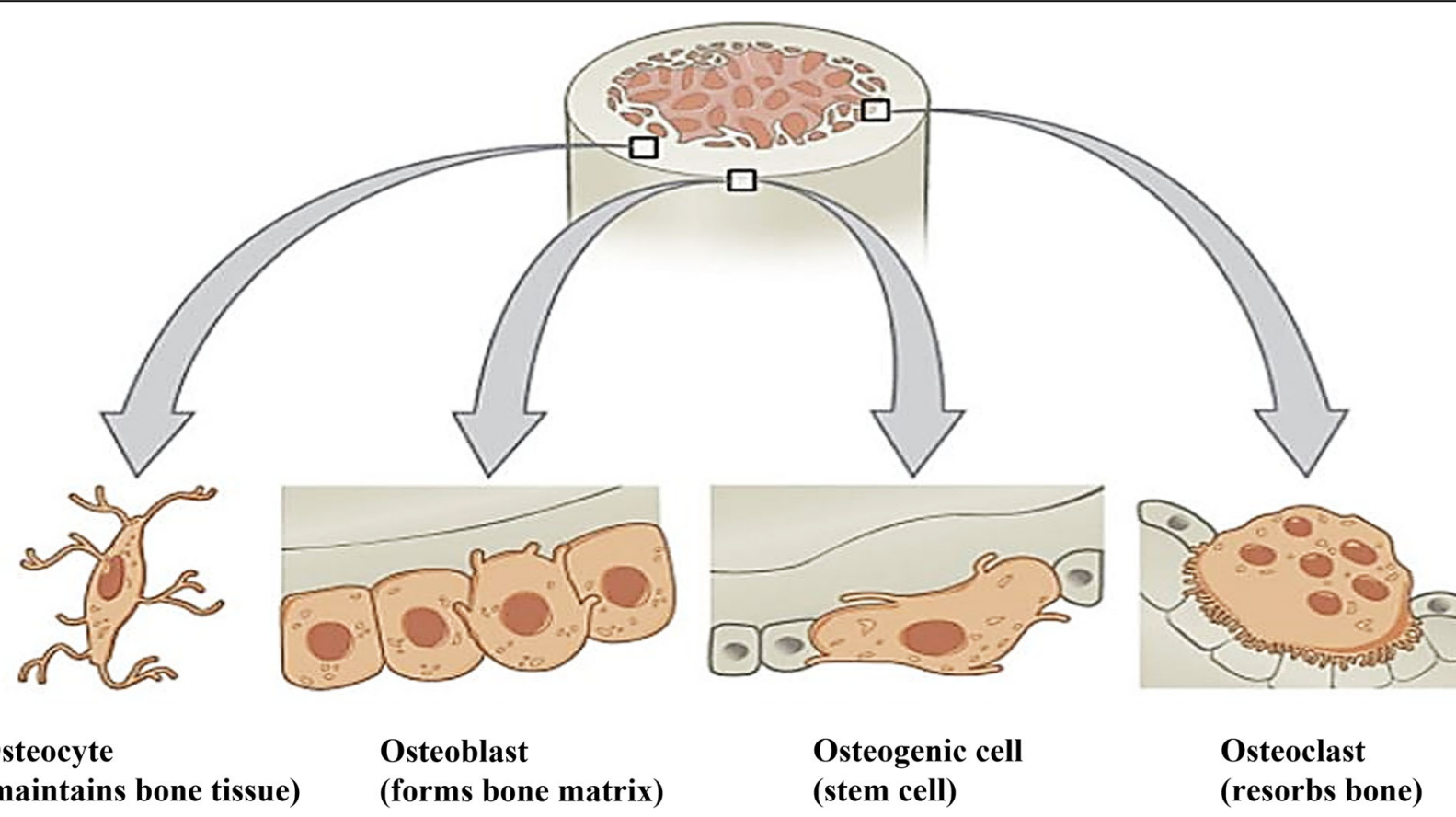

Fig. 3 Classification of bone tissue cells. Osteogenic cells, osteocytes, osteoclasts, and osteoblast are the primary bone cells involved in bone remodeling and formation [48] 
release transforming growth factor- $\beta 1$ (TGF- $\beta 1$ ) and platelet-derived growth factor [56]. Bone morphogenetic proteins are expressed by the osteoprogenitor cells at the fracture site. Inflammatory mediators along with these factors facilitate the proliferation and differentiation of mesenchymal stem cells. Stem cells differentiate into osteoblasts at the periphery of the fracture site during the renewal phase. Intramembranous ossification takes place to develop bone formation after 7 to 10 days of the bone defect. Chondrogenesis occurs at the bulk of the injured tissue, which is mechanically less stable. Endochondral bone and cartilaginous callus formation are initiated through several molecular signaling pathways, and subsequently, the calcified cartilage is replaced with woven bone [57]. In the remodeling phase, the osteoblasts with the restorative ability and the osteoclasts with resorptive ability substitute the already formed bone. Firming up of the fractured callus with a faster healing rate is observed, controlled by the proinflammatory signals and growth hormones. Within some weeks of fracture, the mechanical strength and structure are reinstated, while the molecular and cellular signaling proceeding could take up many years to restore. In a human hip fracture, the bone metabolism controlling hormone's level remains spiked up for over a year [58]. The present review elaborates on the role of polyphenol in bone tissue engineering and their sustained activity of in-loaded electrospun nanofibers. Further, possible challenges and future directions have been discussed in this field.

\section{Contribution of polyphenols in bone tissue regeneration}

Several in vitro and in vivo studies have been reported by many researchers to study the potential role of polyphenols in bone-related cells and bone defect models of experimental animals, respectively [59-66]. We have compiled, in this section, the source of availability, experimental parameters, and salient outcomes of polyphenols in bone tissue regeneration (Table 1).

Curcumin, extracted from the rhizome of Curcuma longa, has become a subject matter as a potential therapeutic agent in the orthopedic field [67]. Curcumin supplementation has been proven to be efficient in preventing and managing osteopenia and has been reported to have beneficial effects on fat metabolism and bone health [68]. The potential mechanisms of curcumin include inhibition of nuclear factor NF- $\mathrm{kB}$, RANKL, inflammatory cytokine synthesis, and the generation of reactive oxygen species and nitric oxide [69, 70]. Ahmed et al. studied the effect of curcumin (CR group) on osteogenic differentiation of bone marrow mesenchymal stem cells (BMSCs) and mouse embryonic fibroblasts (MEFs) compared with all-trans-retinoic acid (ATRA group) and osteogenic medium only as control (OM group). Curcumin stimulated osteogenic differentiation at the cellular and molecular level and increased the expression of osteogenic differentiation markers such as Runx2, osterix, and BMP2. The positive effect of curcumin showed a strong ALP staining intensity, higher mineralization, and upregulation of osteo specific bone markers, confirming an improved osteogenic differentiation of BMSCs compared with ATRA and control (Fig. 4). Moreover, it enhanced the osteogenic differentiation in MEFs reprogrammed with the osteogenic factor hLMP 3, participating in the regulation of bone remodeling [59]. Safali et al. examined the effects of curcumin on bone healing using a total rat femur fracture injury model. Unexpectedly, they found that curcumin had no effect on fracture healing based on biomechanical, radiological, and histological evaluations on 14 and 28 days of investigation. However, they suggested that curcumin's impact may be more noticeable in long-term follow-up investigations because of its potential positive effects, such as activation of cell migration and autophagy during the remodeling phase [60].

Vester et al. examined the dose- and time-dependent effect of green tea extracts (GTE) in human osteoblasts, isolated from femoral heads of patients undergoing total hip replacement. They performed RT-PCR to access the combined effects of GTE $(0.01,0.1$, and $1 \mu \mathrm{g} / \mathrm{ml})$ and $\mathrm{H}_{2} \mathrm{O}_{2}(50 \mu \mathrm{M})$ on the osteogenic genes and found significant expression of bone-related genes such as osteocalcin and collagen $1 \alpha 1$ during osteoblast differentiation. They reported that GTE, at all the concentrations studied, enhanced the mineralized matrix development despite $\mathrm{H}_{2} \mathrm{O}_{2}$ treatment. Further, GTE significantly reduced oxidative stress improving cell viability, suggesting that dietary supplementation of GTE could reduce inflammatory reactions in bone-related diseases such as osteoporosis. Osteoporosis is characterized by structural deterioration of bone tissue and low bone mass causing bone fragility [61]. Shen et al. investigated whether green tea polyphenol (GTP) has the potential to restore bone microstructure in both estrogen adequate (sham group) and estrogen-deficient (OVX group) middle-aged female rats. According to HPLC-ECD and HPLC-UV analyses, GTP $(1000 \mathrm{mg})$ contained a mixture of epigallocatechin gallate $(480 \mathrm{mg})$, epicatechin gallate $(160 \mathrm{mg})$, epicatechin $(60 \mathrm{mg})$, epigallocatechin (103 mg), and catechin $(30 \mathrm{mg})$. The analyses of dual-energy X-ray absorptiometry, micro-computed tomography, and histomorphometry revealed that GTP supplementation increased trabecular thickness, volume, and number and periosteal bone formation rate of tibia shaft, cortical thickness, and femur area. Meanwhile, GTP decreased bone erosion of proximal tibia, trabecular separation, and endocortical bone erosion of the tibia shaft. OVX rat groups 
Table 1 A list of polyphenols and their in vitro and in vivo experimental outcomes in bone tissue engineering

\begin{tabular}{|c|c|c|c|c|c|}
\hline Polyphenols & $\begin{array}{l}\text { Source of } \\
\text { Availability }\end{array}$ & $\begin{array}{l}\text { In Vitro/ In Vivo Biological } \\
\text { Source }\end{array}$ & Experimental Parameters & Salient Outcomes & References \\
\hline Curcumin & $\begin{array}{l}\text { Beijing Solarbio } \\
\text { Science \& } \\
\text { Technology, } \\
\text { China }\end{array}$ & $\begin{array}{l}\text { In vitro: Isolated bone marrow } \\
\text { mesenchymal stem cells } \\
\text { (BMSCs) from } 5 \text { to } 6 \text {-week } \\
\text { male BALB/c mice ( } 15-21 \mathrm{~g} \\
\text { bw) } \\
\text { Mouse embryonic fibroblasts } \\
\text { (MEFs) isolated from pregnant } \\
\text { C57/BL female mice ( } 23-26 \mathrm{~g} \\
\text { bw) at } 13 \text { days of post-coitum }\end{array}$ & $\begin{array}{l}\text { 1) OM group: Cells in } \\
\text { osteogenic medium } \\
\text { 2) CR group: Cells in } \\
\text { osteogenic medium } \\
\text { containing } 15 \mu \mathrm{M} \text { curcumin } \\
\text { 3) ATRA group: Cells in } \\
\text { osteogenic medium } \\
\text { containing } 1 \mu \mathrm{M} \text { all-trans retin- } \\
\text { oic acid }\end{array}$ & $\begin{array}{l}\text { CR group showed an increase in } \\
\text { the osteogenic differentiation } \\
\text { capacity of BMSCs compared to } \\
\text { OM and ATRA groups, as } \\
\text { identified by the mineralization } \\
\text { assay and RT-PCR analysis of bone } \\
\text { markers and OCN expression. } \\
\text { CR group augmented the } \\
\text { osteogenic differentiation of MEFs, } \\
\text { reprogrammed with the } \\
\text { osteogenic factor hLMP-3. Further, } \\
\text { it significantly increased the ex- } \\
\text { pression of the bone markers } \\
\text { Runx2, BMP, and osterix at } 1,2 \text {, } \\
\text { and } 3 \text { weeks of post-transduction. }\end{array}$ & $\begin{array}{l}\text { Ahmed } \\
\text { et al. (2019) } \\
\text { [59] }\end{array}$ \\
\hline
\end{tabular}

\begin{tabular}{|c|c|c|}
\hline Curcumin & $\begin{array}{l}\text { Sigma-Aldrich, } \\
\text { Germany }\end{array}$ & $\begin{array}{l}\text { In vivo: Male Wistar albino rats } \\
(170-210 \mathrm{~g} \text { bw); } n=10 \\
\text { curcumin group and } n=6 \\
\text { control group; transverse } \\
\text { femur shaft fracture model }\end{array}$ \\
\hline $\begin{array}{l}\text { Green tea } \\
\text { extract (GTE) }\end{array}$ & $\begin{array}{l}\text { GTE Sunphenon } \\
90 \text { LB, Taiyo } \\
\text { International, } \\
\text { Germany }\end{array}$ & $\begin{array}{l}\text { In vitro: Primary human } \\
\text { osteoblasts isolated from the } \\
\text { femur heads of patients } \\
\text { undergoing total hip } \\
\text { replacement; } 2.0 \times 10^{4} \text { cells/ } \\
\mathrm{cm}^{2}\end{array}$ \\
\hline
\end{tabular}

Control and curcumin groups (histological, biomechanical, and radiological assessment); 14 and 28 days; $200 \mathrm{mg} / \mathrm{kg}$ oral dose in saline

1) Control: Unstimulated cells 2) Cells stimulated six times with/without $50 \mu \mathrm{M} \mathrm{H}_{2} \mathrm{O}_{2}$ and $0.01,0.1$, and $1 \mu \mathrm{g} / \mathrm{ml}$ of GTE

The curcumin group showed no significant difference in Safali et al. histological, biomechanical, and radiological treatment on 14 days. No significant difference between control and curcumin-treated groups was observed on 28 days.

Low doses of GTE improved mineralization in stimulated osteoblasts with $\mathrm{H}_{2} \mathrm{O}_{2}$ over 21 days. The combined effects of GTE and $\mathrm{H}_{2} \mathrm{O}_{2}$ led to a higher level of gene expression (osteocalcin and collagen1a1) during osteoblasts differentiation. High doses of GTE protected osteoblasts against oxidative stress by reducing intracellular free radicals and LDH leakage.

$\begin{array}{ll}\text { Green tea } & \text { Shili Natural } \\ \text { polyphenols } & \text { Product } \\ \text { (GTP) } & \text { Company, China } \\ & \text { (purity }>80 \%)\end{array}$
(purity > 80\%)
In vivo: Virgin 14-month-old female F344 × BFN1/NIA rats; $n=10 /$ group; postmenopausal bone loss model

\section{Pomace Pomace extract: polyphenolic Croatina grape, extract Alemat, Italy adsorbed Synergoss Red: Synergoss Synthesized from Red HA, $\beta$-TCP pow- ders, and poly (vinyl alcohol)}

Naringin
Sigma-Aldrich, USA (purity > 95\%)
In vitro: Human osteoblast-like SAOS2 cells; $8.5 \times 10^{4}$ cells $/ \mathrm{ml}$

In vitro: $\mathrm{BMSC}$ isolated from lateral tibial tubercle of 4-8 weeks old New Zealand white rabbit $(2.0 \pm 0.5 \mathrm{~kg} \mathrm{bw})$
1) Baseline group: No surgical treatment

2) Estrogen adequate sham group (SH): SH control, SH-L (sham $+0.1 \%$ GTP $(\mathrm{w} / \mathrm{v})$ in drinking water), and $\mathrm{SH}-\mathrm{H}$ (SH + 0.5\% GTP)

3) Estrogen deficient OVX group: OVX ovariectomy control, OVX-L (OVX + 0.1\%), and OVX-H (OVX + 0.5\%)

$0.2 \mathrm{~g} /$ well; 3,5 , and 7 days

OVX group showed a dosedependent increase in periosteal parameters such as mineralized bone surface and bone formation rate. However, the OVX-H group demonstrated a significant difference $(p<0.05)$ compared to other OVX groups, SH groups, and baseline group.

The compound improved earlystage bone matrix deposition and downregulated inflammation. Further, it regulated osteoclastogenesis by the action of antiinflammatory and antioxidant properties.

$0.1,1$, and $10 \mu \mathrm{M} ; 48 \mathrm{~h}$ $1 \mu \mathrm{M} ; 3,7,14$, and 21 days

Naringin stimulated BMSCs differentiation into osteoblasts via the upregulation of miR-20a and the downregulation of PPARY, which was significant compared to control.

$1 \mu \mathrm{M}$ of naringin significantly increased ALP expression after 3 days and showed a higher OC and Col I expression level in 21 days.
(2019) [60]

Vester et al. (2014) [61]

Shen et al. (2009) [62]

Iviglia et al. (2021) [63]

Fan et al. (2015) [64] 
Table 1 A list of polyphenols and their in vitro and in vivo experimental outcomes in bone tissue engineering (Continued)

\begin{tabular}{|c|c|c|c|c|c|}
\hline Polyphenols & $\begin{array}{l}\text { Source of } \\
\text { Availability }\end{array}$ & $\begin{array}{l}\text { In Vitro/ In Vivo Biological } \\
\text { Source }\end{array}$ & Experimental Parameters & Salient Outcomes & References \\
\hline Apigenin & $\begin{array}{l}\text { Institute of } \\
\text { Traditional } \\
\text { Chinese } \\
\text { Medicine, } \\
\text { Nanjing, China }\end{array}$ & $\begin{array}{l}\text { Human fetal bone marrow- } \\
\text { derived from the stem cells } \\
\text { (hMSCs), Prince of Wales } \\
\text { Hospital }\end{array}$ & $\begin{array}{l}\text { Control: Osteogenic induced } \\
\text { medium (OIM) } \\
\text { OIM + apigenin: } 0.1,1 \text {, and } \\
5 \mu \mathrm{M} ; 3,7 \text {, and } 14 \text { days. }\end{array}$ & $\begin{array}{l}\text { Apigenin promoted the } \\
\text { osteogenesis of hMSCs by } \\
\text { stimulating JNK and p38 MAPK } \\
\text { signaling pathways. The effect of } \\
\text { apigenin on mRNA expression } \\
\text { (Runx2 and OPN) in hMSCs was } \\
\text { significantly more significant than } \\
\text { control on } 7 \text { days }(p<0.01) \text {. }\end{array}$ & $\begin{array}{l}\text { Zhang } \\
\text { et al. (2015) } \\
\text { [65] }\end{array}$ \\
\hline Icariin & $\begin{array}{l}\text { Tauto Biotech, } \\
\text { Shanghai, China }\end{array}$ & $\begin{array}{l}\text { In vivo: } \\
\text { 1) } 8 \text {-week-old male C57BL/6 } \mathrm{N} \\
\text { mice ( } 20-25 \mathrm{~g} \text { bw), Oriental } \\
\text { Kobo, Japan; } n=5 \text {; calvarial de- } \\
\text { fect model } \\
\text { 2) } 14 \text {-week-old male mice ( } 28- \\
33 \mathrm{~g} \text { bw); } \mathrm{n}=5 \text {; senescence- } \\
\text { accelerated mouse (SAM) } \\
\text { model }\end{array}$ & $\begin{array}{l}\text { Control group: Calcium } \\
\text { phosphate cement (CPC) } \\
\text { tablet alone, } \\
\text { Icariin-CPC group: CPC } \\
\text { containing } 1 \text { mg of icariin; } 4 \\
\text { and } 6 \text { weeks. } \\
\text { SAM P1-control, SAMP1-icariin, } \\
\text { SAM P6-control, and SAM P6-- } \\
\text { icariin; intraperitoneal injection; } \\
0.2 \text { mg/kg/day for } 6 \text { weeks. }\end{array}$ & $\begin{array}{l}\text { Icariin-CPC group improved } \\
\text { angiogenesis and accelerated } \\
\text { bone tissue regeneration after } \\
\text { transplantation ( } p<0.05 \text { compared } \\
\text { to the control group). } \\
\text { Among the groups, SAM P6-icariin } \\
\text { treated mice significantly in- } \\
\text { creased the trabecular bone thick- } \\
\text { ness and showed a higher new } \\
\text { bone formation rate than the con- } \\
\text { trol group. }\end{array}$ & $\begin{array}{l}\text { Zhao et al. } \\
\text { (2010) [66] }\end{array}$ \\
\hline
\end{tabular}

demonstrated a dose-dependent increase with GTP in the parameters such as mineralized bone surface and bone formation rate. In contrast, $\mathrm{SH}$ rat groups with GTP did not show any significant difference [62].

A new ceramic granulated biomaterial (Synergoss Red, SR) was functionalized with red grape pomace extract containing polyphenolic mixture to study its regeneration effect on periodontal tissues [63]. The primary polyphenols present in pomace extract, including quercetin [71], kaempferol [72], and catechins [73], were shown to direct osteogenic differentiation in different mesenchymal stem cell types. The bone filler, SR, was synthesized from the mixture of $47 \mathrm{wt} \%$ of hydroxyapatite (HA) and tricalcium phosphate $(\beta-\mathrm{TCP})$ powders with the binding agent, $3 \mathrm{wt} \%$ of poly(vinyl alcohol). A $0.2 \mathrm{~g}$ of Synergoss Red was capable of adsorbing around $0.951 \mathrm{mg}$ of polyphenols. Several studies have confirmed that polyphenols exhibit antioxidant properties naturally and involve many bone regeneration mechanisms [74, 75]. In the present study, the compound showed free radical inhibition by $72.8 \%$, characterized by a $\mathrm{DPPH}$ assay. Polyphenols in Synergoss Red significantly reduced the level of iNOS expression $(p<0.0001)$ compared to control (bone filler alone). The antiinflammatory and antioxidant properties of polyphenols in pomace extract exerted a protective role in bone loss by reducing osteoclastogenesis and enhancing osteoblastogenesis.

Naringin, a dihydrotestosterone flavonoid compound, has been reported to improve bone density, inhibit bone loss, and augment biomechanical anti compression performance [76]. Fan et al. studied the osteogenic differentiation ability of naringin in BMSCs collected from the lateral tibial tubercle of the white rabbit. The treatment of BMSCs with $0.1,1$, and $10 \mu \mathrm{M}$ naringin for $48 \mathrm{~h}$ significantly increased the mRNA expression levels of OC, ALP, and Col I, compared to control (without additive). The western blot and RT-PCR analyses showed a decreased PPAR $\gamma$ protein expression and an increased miR-20a marker expression in BMSCs when the cells were treated with $1 \mu \mathrm{M}$ of naringin for 21 days. The results suggested that naringin, as a potential drug, may promote BMSCs' differentiation into the osteoblasts during osteoporosis treatment [64]. Apigenin (4',5,7-trihydroxyflavone), a member of the flavone family of flavonoid compounds, was reported to possess remarkable anti-carcinogenic, antioxidant, and estrogenic properties [77]. Zhang et al. studied the transducing ability of apigenin in hMSCs into osteoblasts and reported that apigenin significantly increased activity of ALP and the mineralized nodule formation in a dose-dependent manner [65]. The cells treated with $5 \mu \mathrm{M}$ of apigenin significantly increased Runx2 and OSX protein expression through JNK and p38 MAPK pathways, which play a pivotal role in regulating the osteogenic differentiation of MSCs [78].

The research group of Zhao et al. evaluated the osteogenic effect of icariin through in vitro and in vivo biological characterizations [66]. Icariin, a flavonoid glycoside isolated from the herb of Epimedium pubescens, has been reported to have potential therapeutic effects on a rat model of osteoporosis induced by ovariectomy [79, 80]. Preosteoblast MC3T3-E1 and fibroblast NIH3T3 cells were used for the in vitro osteogenesis analysis in work. MC3T3-E1 cells treated with $10^{-5} \mathrm{M}$ of icariin exhibited a significant increase in ALP activity, Runx2, bone sialoprotein (BSP), and osteocalcin (OCN) expression at day 3 . In contrast, icariin-treated fibroblast cell line NIH3T3 had not shown remarkable ALP and protein expression. Two types of animal 


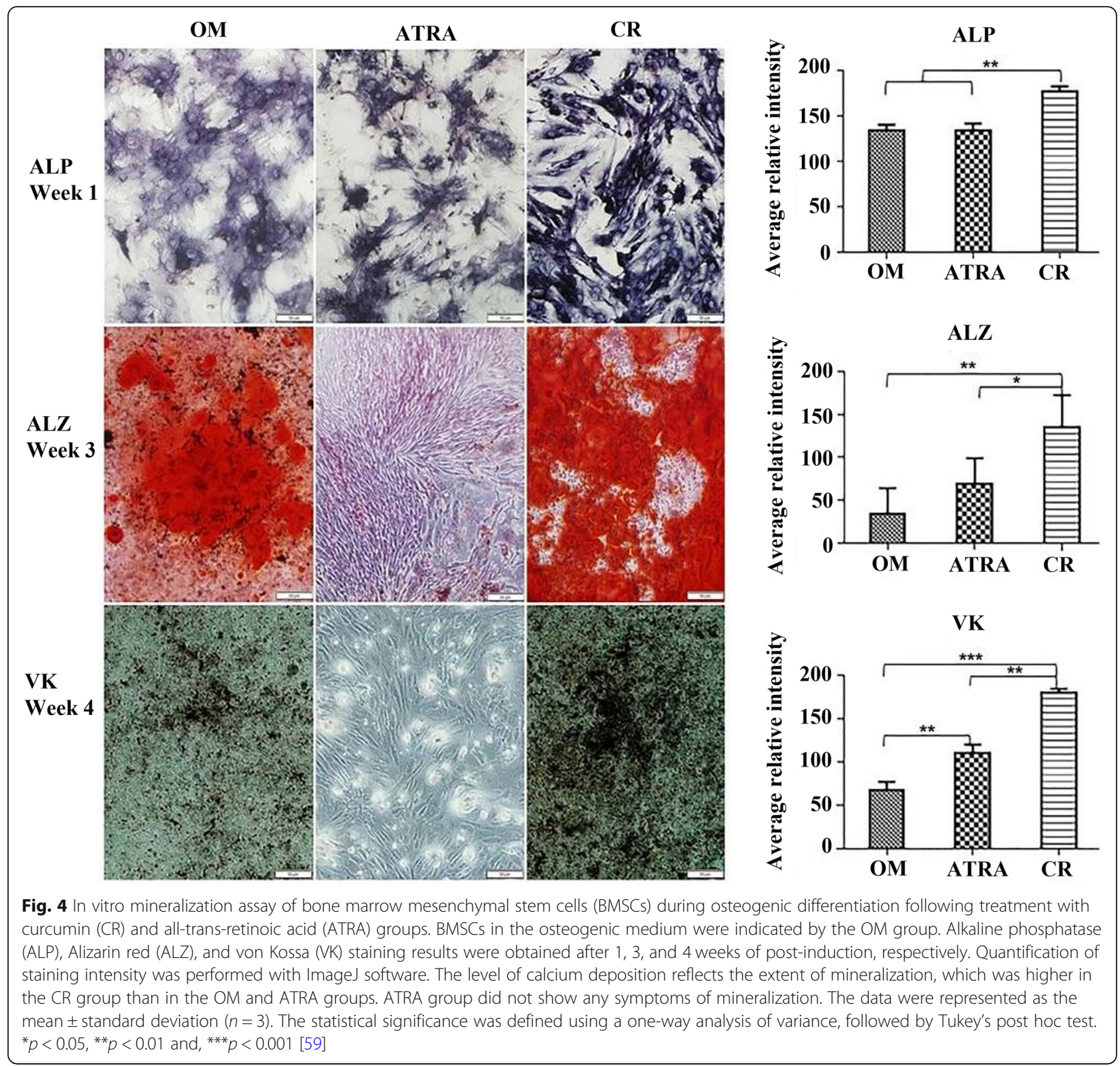

models, viz. calvarial defect model and senescenceaccelerated mouse models, were investigated to study icariin's bone regeneration ability in vivo. In the calvarial defect model, eight-week-old male C57BL/6NJ mice were transplanted with icariin-calcium phosphate cement (CPC) tablets or CPC tablets only (control) to evaluate bone tissue regeneration after 4 and 6 weeks. The icariin-CPC group demonstrated significant new bone formation and new bone thickness at 4 weeks and 6 weeks, respectively, compared to the control group. The senescence models (SAM P1 and SAM P6) revealed that icariin injected mice could enhance bone formation in vivo. Overall, the results suggested that icariin could act as a strong candidate for an osteogenic compound in bone tissue engineering applications.

\section{Advantages of polyphenol-loaded electrospun nanofibers}

Biocompatible and naturally available biopolymers and synthetic polymers have been widely used to prepare electrospun nanofibrous mats for tissue engineering applications [81-83]. The current situation demands the fabrication of highly bioactive scaffolds with superior biocompatibility, mechanical properties, and remodeling potential to repair the damaged tissues. The same can be achieved by either surface functionalization or 
incorporation of bioactive materials in the nanofiber membrane. The nanofiber scaffold's primary goal is to provide an appropriate microenvironment for bone tissue to restore and facilitate the bone tissue regeneration process [84]. Ideally, the fabrication of polyphenolloaded electrospun nanofibers scaffolds has some advantages in bone tissue regeneration applications. They exert anti-inflammatory and antioxidant activity, improve bioavailability, and release the polyphenols at a sustained level in the cell differentiation site. They provide an active shield against infection, minimize toxicity to other tissues, and enhance the bone remodeling process via calcium deposition and activation of several bone-specific proteins [85]. The incorporated biomolecules into the scaffold can interact with the biomaterial's surface through various physical and chemical forces, including hydrogen bonding, hydrophobic interaction, and Van der Waals force [86]. It was reported that the ion complexation property of bioactive molecules could cause protein deactivation and denaturation [87, 88]. The surface-functionalization of nanofibers with bioactive molecules via non-covalent immobilization techniques protects the nature of the bioactive molecules and the structure of biomaterials [89, 90]. Further, the bioactive molecules improve hydrophilicity and surface charge of the nanofiber's surface, establishing a favorable milieu, enhancing the protein adsorption on its surface [91, 92]. Henceforth, the fabrication of electrospun nanofibers using biocompatible polymer or specific polyphenols expands their mechanical, biological, and functional properties, leading to cell attachment, cell migration, and cell proliferation [93]. A list of polyphenols incorporated electrospun nanofibers and their application in bone tissue regeneration has been provided in Table 2.

Jain et al. prepared curcumin-loaded PCL electrospun nanofibers (CU1 and CU5) to investigate the influence of curcumin drug release from the scaffold on osteogenesis and compare the results with PCL scaffold without drugs (CU0). It was found that both fiber mats released around $18 \%$ of the drugs on day 3 . However, CU1 and CU5 showed different drug releases of 42 and 50\%, respectively, on day 6 of the investigation. The in vitro results using MC3T3-E1 mouse pre-osteoblasts demonstrated that ALP activity of the scaffolds was found in the order of CU1 $>$ CU0 $>$ CU5. The optimized concentration of curcumin and sustained drug release from CU1 helped increase osteogenic expression compared to CU5, which had a high drug loading content [94]. Sedghi et al. developed bioactive molecule-loaded coaxial electrospun nanofibrous scaffolds with antiinfective properties to prove effective bone tissue regeneration. The bioactive complex was composed of zinccurcumin (Zn-CUR) and graphene oxide. The developed core-shell nanofiber membrane comprised a blend of polyvinyl alcohol and carboxymethyl chitosan (PVA/ $\mathrm{CMCh}$ ) in the shell and 4armPCL/Zn-CUR in the core part. Cellular morphology and MTT (3-(4,5-Dimethylthiazol-2-yl)-2,5-Diphenyltetrazolium bromide) assay showed that Zn-CUR-containing scaffolds substantially supported cellular adhesion, spreading, and proliferation compared to drug-free scaffolds. Moreover, the Zn-CUR complex in the scaffolds increased ALP activity and matrix mineralization and reduced postoperative infection with an excellent antibacterial activity as the metalorganic complex improves the bioavailability of curcumin. Further, complex localization into the core part of the core-shell nanofiber leads to its controlled release, enhancing its therapeutic efficiency [95].

Dhand et al. fabricated catecholamine contained collagen nanofiber with excellent mechanical property without interfering with hydrophilicity of the nanofiber surface [102]. The in vitro cell viability and calcium deposition analysis confirmed that the highly biocompatible catecholamine contained composite nanofiber enhanced calcium mineralization (Fig. 5). Lee et al. prepared catechin coated functional PCL nanofibrous scaffolds with antioxidative property and calcium-binding ability to achieve an enhanced osteogenic differentiation of human adipose-derived stem cells (hADSCs). The scaffold was reported to significantly promote in vivo bone formation in a critical-sized calvarial bone defect. The scaffolds were divided into five different groups, no treatment, PCL scaffold (PCL), catechin coated PCL scaffold (PCL-Cat), PCL with hADSCs (PCL-hADSC), and catechin-coated PCL scaffold with hADSCs (PCLCat-hADSC). The results of micro-CT images and histological examination demonstrated that PCL-Cat-hADSC showed an improved tissue regenerative efficacy by the influence of catechin (Fig. 6) [96].

Jeong et al. developed polyhedral oligomeric silsesquioxane-epigallocatechin gallate (POSS-EGCG) loaded poly (vinylidene fluoride) electrospun nanofiber to investigate bone tissue regeneration [97]. Epigallocatechin gallate (EGCG), a polyphenolic flavonoid derived from a variety of plants, has been reported to impede lipopolysaccharide (LPS)-stimulated osteoclastic bone resorption and reduce inflammatory bone loss in bone metabolism [103, 104]. It was found that the concentration of $6 \mathrm{wt} \%$ POSS-EGCG conjugates (PE06) loaded PVDF nanofibrous scaffold showed betterment in physiochemical and mechanical properties than 0,2 , and 4 wt\% conjugate loaded scaffolds (PVDF, PE02, and PE04, respectively). The in vitro osteogenic and osteoblast differentiation results confirmed that PE06 exhibited a higher ALP activity and bone mineralization than other scaffolds. Our recent work demonstrated a promising PCL-gelatin-( $\mathrm{Zn}+\mathrm{Q}(\mathrm{PHt}))$ nanofibrous scaffold to 
Table 2 The preparation method of polyphenol-loaded electrospun nanofiber, nanofiber diameter distribution, and their contribution to bone tissue engineering are listed

\begin{tabular}{|c|c|c|c|c|c|}
\hline $\begin{array}{l}\text { Polyphenol } \\
\text { Additives }\end{array}$ & $\begin{array}{l}\text { Polymeric } \\
\text { Composite with } \\
\text { Additives and } \\
\text { their Labels }\end{array}$ & $\begin{array}{l}\text { Electrospinning } \\
\text { Method and the } \\
\text { Nanofiber } \\
\text { Diameter } \\
\text { Distribution }\end{array}$ & $\begin{array}{l}\text { In Vitro / In Vivo } \\
\text { Biological Source }\end{array}$ & Salient Outcomes & References \\
\hline Curcumin & $\begin{array}{l}\text { PCL-curcumin } \\
\text { (CU0, CU1, and } \\
\text { CU5) }\end{array}$ & $\begin{array}{l}\text { Conventional } \\
\text { method/ } \\
\text { CU0: } 840 \pm 130 \mathrm{~nm} \\
\text { CU1: } 827 \pm 129 \mathrm{~nm} \\
\text { CU5: } 680 \pm 110 \mathrm{~nm}\end{array}$ & $\begin{array}{l}\text { In vitro: MC3T3-E1 } \\
\text { mouse pre-osteoblasts; } \\
1,5 \text { and } 10 \text { days }\end{array}$ & $\begin{array}{l}\text { CU1 nanofibers showed significant } \\
\text { osteogenesis leading to mineralization } \\
\text { compared to CU0 and CU5 nanofibers. }\end{array}$ & $\begin{array}{l}\text { Jain et al. } \\
\text { (2016) [94] }\end{array}$ \\
\hline Curcumin & $\begin{array}{l}\text { 4-arm PCL-(Zn- } \\
\text { curcumin)/ PVA- } \\
\text { CMCh-GO (N1, N2, } \\
\text { N3, N4, and N5) }\end{array}$ & $\begin{array}{l}\text { Coaxial method/ } \\
\text { N1: } 205 \pm 92 \mathrm{~nm} \\
\text { N2: } 186 \pm 78 \mathrm{~nm} \\
\text { N3: } 174 \pm 56 \mathrm{~nm} \\
\text { N4: } 153 \pm 31 \mathrm{~nm} \\
\text { N5: } 156 \pm 34 \mathrm{~nm}\end{array}$ & $\begin{array}{l}\text { In vitro: MG-63 human } \\
\text { osteoblasts; } 7 \text { and } 14 \\
\text { days. }\end{array}$ & $\begin{array}{l}\text { The experimental nanofiber (N4) showed } \\
\text { an increased ALP activity, enhanced matrix } \\
\text { mineralization, and reduced post-operative } \\
\text { infection. }\end{array}$ & $\begin{array}{l}\text { Sedghi } \\
\text { et al. (2018) } \\
\text { [95] }\end{array}$ \\
\hline Catechin (Cat) & PCL-Cat & $\begin{array}{l}\text { Conventional } \\
\text { method/ } \\
\text { PCL: } 200 \pm 150 \mathrm{~nm} \\
\text { PCL-Cat: } 200 \pm 150 \\
\mathrm{~nm}\end{array}$ & $\begin{array}{l}\text { In vivo: critical-sized cal- } \\
\text { varial bone defect } \\
\text { mouse model; } 4 \text { mm } \\
\text { defect size; } 8 \text { weeks } \\
\text { Control (no treat), PCL } \\
\text { scaffold, PCL-Cat, PCL- } \\
\text { hADSC, and PCL-Cat- } \\
\text { hADSC groups }\end{array}$ & $\begin{array}{l}\text { PCL-Cat-hADSC demonstrated a high bone } \\
\text { coverage and bone volume than other } \\
\text { groups on } 8 \text { weeks of post-transplantation } \\
(p<0.01 \text { vs. control; } p<0.05 \text { vs. PCL) }\end{array}$ & $\begin{array}{l}\text { Lee et al. } \\
\text { (2017) [96] }\end{array}$ \\
\hline $\begin{array}{l}\text { Polyhedral } \\
\text { oligomeric } \\
\text { silsesquioxane- } \\
\text { epigallocatechin gall- } \\
\text { ate (POSS-EGCG) }\end{array}$ & $\begin{array}{l}\text { Poly(vinylidene } \\
\text { fluoride)-POSS- } \\
\text { EGCG } \\
\text { (PVDF, PE02, PE04, } \\
\text { and PE06) }\end{array}$ & $\begin{array}{l}\text { Conventional } \\
\text { method/ } \\
\text { PVDF: } 1033 \pm 270 \\
\mathrm{~nm} \\
\text { PE02: } 971 \pm 262 \mathrm{~nm} \\
\text { PE04: } 936 \pm 223 \mathrm{~nm} \\
\text { PE06: } 1094 \pm 394 \\
\mathrm{~nm}\end{array}$ & $\begin{array}{l}\text { MC3T3-E1 osteoblasts; } \\
3,5,7 \text {, and } 14 \text { days; } 1 \times \\
10^{4} \text { cells }\end{array}$ & $\begin{array}{l}\text { POSS-EGCG conjugation improved } \\
\text { bioactivity of PVDF nanofiber; PEO6 showed } \\
\text { maximum ALP activity and improved bone } \\
\text { mineralization ( } p<0.05 \text { vs. PVDF). }\end{array}$ & $\begin{array}{l}\text { Jeong et al. } \\
\text { (2019) [97] }\end{array}$ \\
\hline $\begin{array}{l}\text { Zinc quercetin- } \\
\text { phenanthroline }(\mathrm{Zn}+ \\
\mathrm{Q}(\mathrm{PHt}))\end{array}$ & $\begin{array}{l}\text { PCL-gelatin- }(\mathrm{Zn}+ \\
\mathrm{Q}(\mathrm{PHt}))\end{array}$ & $\begin{array}{l}\text { Conventional } \\
\text { method/ } \\
\text { PCL-gelatin: } 260- \\
500 \mathrm{~nm} \\
\text { PCL-gelatin-(Zn + } \\
\text { Q(PHt)): } 250-600 \mathrm{~nm}\end{array}$ & $\begin{array}{l}\text { In vitro: MG-63 } \\
\text { osteoblast-like cells; } 3 \\
\text { and } 7 \text { days }\end{array}$ & $\begin{array}{l}\text { PCL-gelatin- }(\mathrm{Zn}+\mathrm{Q}(\mathrm{PHt})) \text { scaffold showed } \\
\text { more relative ALP activity than PCL-gelatin } \\
\text { on } 3 \text { and } 7 \text { days of post-treatment; Runx } 2 \\
\text { and type } 1 \text { collagen mRNAs expression } \\
\text { were also found more significant in PCL- } \\
\text { gelatin-( } \mathrm{Zn}+\mathrm{Q}(\mathrm{PHt}) \text { scaffold. }\end{array}$ & $\begin{array}{l}\text { Preeth } \\
\text { et al. (2021) } \\
\text { [98] }\end{array}$ \\
\hline Resveratrol (RSV) & $\begin{array}{l}\text { PCL-RSV and PLA- } \\
\text { RSV }\end{array}$ & $\begin{array}{l}\text { Conventional } \\
\text { method/ } \\
\text { PCL-RSV: } 0.97 \pm \\
0.45 \mu \mathrm{m} \\
\text { PLA-RSV: } 0.45- \\
1.20 \mu \mathrm{m}\end{array}$ & $\begin{array}{l}\text { In vitro: STRO-1 positive } \\
\text { stem cells (STRO- } 1^{+} \\
\text {cells); } 1,3,7,14 \text {, and } 21 \\
\text { days }\end{array}$ & $\begin{array}{l}\text { Both materials exhibited the same level of } \\
\text { osteoinductive capacity; Only PLA-RSV in- } \\
\text { duced expression of osteoblasts inhibiting } \\
\text { osteoclast differentiation. }\end{array}$ & $\begin{array}{l}\text { Riccitiello } \\
\text { et al. (2018) } \\
\text { [99] }\end{array}$ \\
\hline Icariin (ICA) & $\begin{array}{l}\text { PG: PCL-gelatin } \\
\text { nanofiber without } \\
\text { drug } \\
\text { PGM: nanofiber } \\
\text { with MOX } \\
\text { PGI: nanofiber with } \\
\text { ICA } \\
\text { PGMI: nanofiber } \\
\text { with MOX-ICA }\end{array}$ & $\begin{array}{l}\text { Coaxial method/ } \\
\text { PG: } 0.4-0.8 \mu \mathrm{m} \\
\text { PGM: } 0.4-0.8 \mu \mathrm{m} \\
\text { PGI: } 0.7-1 \mu \mathrm{m} \\
\text { PGMI: } 0.7-1 \mu \mathrm{m}\end{array}$ & $\begin{array}{l}\text { In vitro: MC3T3-E1 cells; } \\
7,14 \text {, and } 21 \text { days } \\
\text { In vivo: New Zealand } \\
\text { White rabbits; } 2.5 \mathrm{~kg} \\
\text { bw; } 3 \text { groups; } 1,2 \text {, and } \\
3 \text { months }\end{array}$ & $\begin{array}{l}\text { PGI promoted a significant ALP secretion } \\
\text { among all the fiber membranes, whereas } \\
\text { PGMI demonstrated a higher expression of } \\
\text { OCN and COL I. } \\
\text { PGMI group displayed a high quality of } \\
\text { bone formation compared to untreated } \\
\text { and PG groups at } 3 \text { months of post- } \\
\text { surgery. }\end{array}$ & $\begin{array}{l}\text { Gong et al. } \\
\text { (2019) [100] }\end{array}$ \\
\hline Icariin & $\begin{array}{l}\text { PCL-gelatin-icariin } \\
\text { (PGI0, PGI0.005, } \\
\text { PGI0.01, PGI0.05, } \\
\text { PGI0.1, and PGI0.5) }\end{array}$ & $\begin{array}{l}\text { Conventional } \\
\text { method/ } \\
\text { PGI0: } 0.26 \pm 0.06 \mu \mathrm{m} \\
\text { PGI0.005: } 0.19 \pm \\
0.05 \mu \mathrm{m} \\
\text { PGI0.01: } 0.17 \pm \\
0.04 \mu \mathrm{m} \\
\text { PGI0.05: } 0.16 \pm \\
0.05 \mu \mathrm{m} \\
\text { PGI0.1: } 0.17 \pm \\
0.04 \mu \mathrm{m}\end{array}$ & $\begin{array}{l}\text { In vitro: MC3T3-E1 cells; } \\
14 \text { and } 21 \text { days }\end{array}$ & $\begin{array}{l}\text { PGI0.05 efficiently enhanced the expression } \\
\text { of ALP, OCN, COL 1, and calcium } \\
\text { deposition compared to other scaffolds. }\end{array}$ & $\begin{array}{l}\text { Gong et al. } \\
\text { (2018) [101] }\end{array}$ \\
\hline
\end{tabular}


Table 2 The preparation method of polyphenol-loaded electrospun nanofiber, nanofiber diameter distribution, and their contribution to bone tissue engineering are listed (Continued)

\begin{tabular}{lllll}
\hline $\begin{array}{l}\text { Polyphenol } \\
\text { Additives }\end{array}$ & $\begin{array}{l}\text { Polymeric } \\
\text { Composite with } \\
\text { Additives and } \\
\text { their Labels }\end{array}$ & $\begin{array}{l}\text { Electrospinning } \\
\text { Method and the } \\
\text { Nanofiber } \\
\text { Diameter } \\
\text { Distribution }\end{array}$ & $\begin{array}{l}\text { In Vitro / In Vivo } \\
\text { Biological Source }\end{array}$ & Salient Outcomes \\
& & & \\
& & & \\
& $0.04 \mu \mathrm{m}$ & $0.16 \pm$ \\
\end{tabular}

increase osteoblastogenesis, leading to bone formation. The metal-organic complex $(\mathrm{Zn}+\mathrm{Q}(\mathrm{PHt}))$ was synthesized by refluxing a methanolic mixture of phenanthroline (PHt), quercetin, and $\mathrm{Zn}^{2+}$ ions. The fibers diameter distribution of PCL-gelatin-(Zn+Q(PHt)) scaffold was $250-500 \mathrm{~nm}$ with $72 \%$ of bioactive complex entrapped into nanofiber matrix. The in vitro and in vivo biological studies indicated that the scaffold exhibited a better osteogenic differentiation with a large amount of Runx2 and type 1 collagen mRNAs expression than the PCLgelatin nanofiber alone [98].

Resveratrol (RSV), a natural polyphenolic compound, is present in numerous plant products, including red wine. Its biological effects are antioxidant, anticancer, anti-inflammatory, cardiovascular protection, antiaging, and bone-protective property $[105,106]$. It stimulates osteoblast differentiation in a dose-dependent manner activating MAPK signaling pathway and further inhibits bone resorption by constraining RANKL-induced osteoclast differentiation [107]. RSV has been used for the alveolar socket reduction and remodeling of the dental implant after removing the tooth $[108,109]$. However, the oral bioavailability of RSV is limited due to its low water solubility, poor pharmacokinetics, and instant metabolism. Hence, it is required to formulate a sound delivery system to deliver RSV at the target site [110]. Riccitiello et al. prepared RSV-loaded defect-free PCL (PCL-RSV) and poly(lactic) acid electrospun nanofibers (PLA-RSV) for the treatment of alveolar bone defect. Both PCL-RSV and PLA-RSV promoted human dental

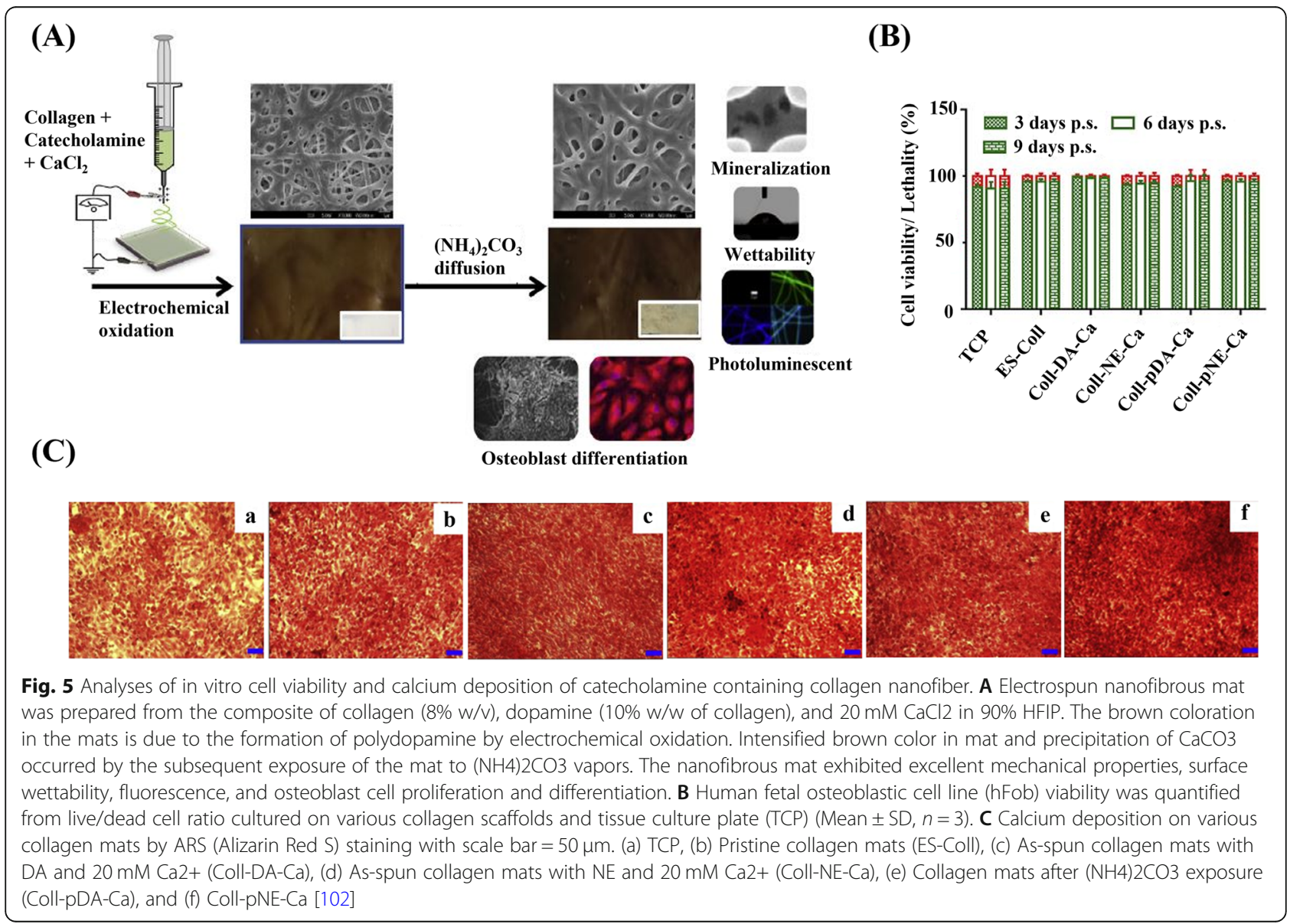




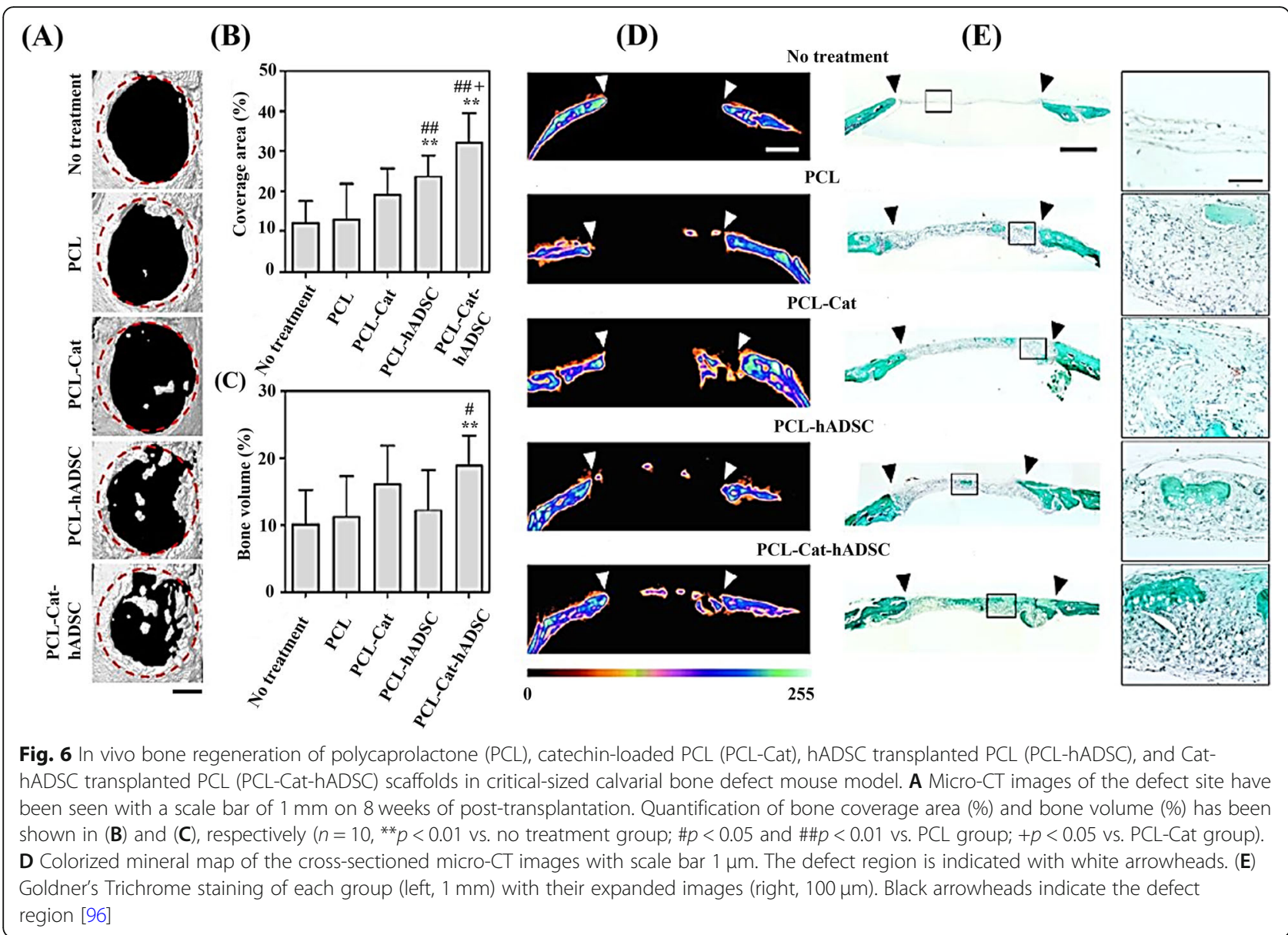

pulp stem cells (DPSCs) differentiation into osteoblastlike phenotype, triggering the expression of early (Runx2 and OSX) and late (OCN, ONN, OPN, and BSP) osteoblast differentiation markers. Though PLA-RSV contained a lower number of drugs than PCL-RSV, only the former scaffold could induce osteoblast differentiation and inhibit osteoclast differentiation, suggesting its use in preserving the post-extraction alveolar ridge volume during bone resorption and new bone formation [99].

Gong et al. fabricated an icariin-loaded core-shell electrospun membrane to imitate artificial periosteum for bone tissue regeneration. They prepared different core-shell type electrospun nanofibrous scaffolds from PCL and gelatin polymeric components and labeled them as PG (without drug), PGM (MOX loaded), PGI (icariin loaded), and PGMI (dual drug-loaded). All the prepared scaffolds showed membrane degradation up to $60-80 \%$ for over 2 months. The sustained release of icariin from the nanofiber PGI helped augment osteogenic differentiation, especially ALP expression and $\mathrm{Ca}^{2+}$ deposition. However, dual drug-loaded PGMI was effective in showing more expression of $\mathrm{OCN}$ and $\mathrm{COL}$
I. The histology, immunohistochemical and radiographic results demonstrated that the quality of bone formation and the quantity of bone mass was highly enhanced in the PGMI group than that of PG and untreated rabbit groups [100]. In another research work, the same researcher prepared various PCL/gelatin nanofibrous scaffolds with different concentrations of icariin viz. $0,1.2,2.4,12,24$, and $120 \mathrm{mg} / \mathrm{ml}$ and labeled as PGI0, PGI0.005, PGI0.01, PGI0.05, PGI0.1, and PGI0.5, respectively. They found that PGI0.05 possessed exceptional overall performances related to bone regeneration by accelerating OCN, ALP, COL I, and calcium expression. Further, the degradation behavior and mechanical strength of PGI0.05 were also reported to fulfill the requirements of an artificial periosteum. Hence, the PGI0.05 scaffold was recommended as a potential artificial periosteum to repair large-sized bone defects [101]. The compilation of research materials demonstrates that polyphenols contribute to enhancing bone tissue regeneration as the drug molecules alone or the active components in scaffolds like electrospun nanofibers. 


\section{Conclusion and future perspectives}

This review demonstrated the in vitro and in vivo bone tissue regenerating ability of polyphenols with or without the electrospun nanofibrous scaffold. The beneficial properties of polyphenols loaded nanofibrous scaffolds are antioxidant property, biocompatibility, porosity, flexibility, tensile strength, cell proliferation, and osteogenic differentiation. However, there are some issues to be addressed in this field. (1) Though many reports are available to study polyphenols loaded incorporated electrospun nanofiber for bone tissue regeneration, the nanofibers prepared in their studies are mostly accomplished using the conventional electrospinning method. Only a few reports are available to prepare core-shell nanofibers using coaxial methods, releasing polyphenols with a desired drug delivery profile. According to the literature reports, the core-shell structured nanofiber permits the encapsulation of sensitive bioactive molecules into the core portion for better loading and controlled long-term release compared to normal nanofiber [95]. Hence, the researchers should focus on loading polyphenols into differently structured nanofibers to increase their therapeutic efficacy. (2) The researchers should conduct drug loading/release profiles using different polyphenols in the nanofibrous mats to provide comparative data. (3) The bone tissue regeneration phase, in which the polyphenols contribute more effectively, should be investigated through many systematic biological studies. (4) The selection of suitable polyphenols for scaffold fabrication is still an open question in most cases due to the non-specific regulations and theoretically indistinguishable structure-function performance. So, more works need to be carried out to identify which polyphenols category is most suitable for bone tissue engineering applications. (5) The nature and functionality of the polyphenols should be analyzed when they are released from the nanofibrous mats because the polyphenols may alter their molecular structures and dissolution depending on the external medium. We are suggesting the following comments for the future direction in this field. (1) Characterizing more in vitro and in vivo biological studies based on polyphenol-loaded electrospun nanofibrous mats prepared by the coaxial method. (2) Tracking the presence of polyphenols and determining their quantity in different bone tissue regeneration phases using appropriate sophisticated methods. (3) Analyzing the nature of polyphenols before and after loading into the scaffolds using spectral characterizations such as HPLC and NMR. (4) Performing more molecular level studies to gain insights into the cellular mechanism in which polyphenols are involved. We anticipate that researchers with interdisciplinary backgrounds will develop bone tissue regeneration by emphasizing polyphenols' importance and suggestions.

\begin{abstract}
Abbreviations
GO: Graphene oxide; CMCh: Carboxymethyl chitosan; Zn-CUR: Zn-Curcumin complex; PLA: Polylactic acid; PCL: Polycaprolactone; GEL: Gelatin; CAT: Catechin; BMC: Bioactive metal complex; BMP: Bone morphogenetic protein; MOX: Moxifloxacin; BMSCs: Bone marrow mesenchymal stem cells; bw: Body weight; ALP: Alkaline phosphatase; OCN: Osteocalcin; OSX: Osterix/ Transcription factor Sp7; JNK: c-Jun N-terminal kinase; ONN: Osteonectin; OPN: Osteopontin; Runx2: Runt-related transcription factor 2; BSP: Bone sialoprotein; RANKL: Receptor activator of nuclear factor kappa-B ligand; Col I: Collagen type 1; PPARy: Peroxisome proliferator- activated receptor gamma; HPLC: High performance liquid chromatography; NMR: Nuclear magnetic resonance; RT-PCR: Real-time polymerase chain reaction
\end{abstract}

\section{Acknowledgements \\ Not applicable.}

\section{Authors' contributions}

DRP, SR and D-WH developed the idea and structure of the review article. ISR and DRP wrote the manuscript collecting the materials from MV, DL and $\mathrm{S}-\mathrm{HH}, \mathrm{BK}, \mathrm{SR}$ and D-WH revised and improved the manuscript. BK and D-WH supervised the manuscript. All the authors have given approval to the final version of the manuscript.

\section{Funding}

This research was supported by a DST-Inspire Faculty (Grant No. DST/INSPIRE/04/2015/001945), sponsored, and managed by the Department of Science \& Technology, India. Further, this work was supported by the National Research Foundation of Korea (NRF) grant funded by the Korean government (MSIT) (Grant No. 2021R1A2C2006013) and financially supported by the 2021 Post-Doc. Development Program of Pusan National University.

Availability of data and materials

Not applicable.

\section{Declarations}

Ethics approval and consent to participate

Not applicable.

Consent for publication

Not applicable.

\section{Competing interests}

The authors declare that they have no competing interests.

\section{Author details}

${ }^{1}$ BIO-IT Fusion Technology Research Institute, Pusan National University, Busan 46241, South Korea. ${ }^{2}$ Chemical Biology and Nanobiotechnology Laboratory, AU-KBC Research Centre, Anna University, MIT Campus, Chromepet, Chennai 600 044, India. ${ }^{3}$ CSIR-Central Leather Research Institute, Adyar, Chennai 600 020, India. ${ }^{4}$ BMG Inc., Kyoto 601-8023, Japan.

${ }^{5}$ Department of Mechanical Engineering, Sejong University, Seoul 05006, South Korea. ${ }^{6}$ Dental Life Science Research Institute / Innovation Research \& Support Center for Dental Science, Seoul National University Dental Hospital, Seoul 03080, South Korea. 'Department of Cogno-Mechatronics Engineering, College of Nanoscience \& Nanotechnology, Pusan National University, Busan 46241, South Korea.

Received: 29 July 2021 Accepted: 30 August 2021

Published online: 25 September 2021

\section{References}

1. Scalbert A, Manach C, Morand C, Rémésy C, Jiménez L. Dietary polyphenols and the prevention of diseases. Crit Rev Food Sci Nutr. 2005;45:287-306.

2. Rah DK, Han D-W, Baek HS, Hyon S-H, Park BY, Park J-C. Protection of rabbit kidney from ischemia/reperfusion injury by green tea polyphenol pretreatment. Arch Pharm Res. 2007;30:1447-54.

3. Nicolin V, De Tommasi N, Nori SL, Costantinides F, Berton F, Di Lenarda R. Modulatory effects of plant polyphenols on bone remodeling: a prospective view from the bench to bedside. Front Endocrinol. 2019;10:494. 
4. Park YH, Han D-W, Suh H, Ryu GH, Hyon SH, Cho BK, et al. Protective effects of green tea polyphenol against reactive oxygen species-induced oxidative stress in cultured rat calvarial osteoblast. Cell Biol Toxicol. 2003;19:325-37.

5. Rah DK, Han DW, Baek HS, Hyon SH, Park JC. Prevention of reactive oxygen species-induced oxidative stress in human microvascular endothelial cells by green tea polyphenol. Toxicol Lett. 2005;155:269-75.

6. Fine AM. Oligomeric proanthocyanidin complexes: history, structure, and phytopharmaceutical applications. Altern Med Rev. 2000;5:144-51.

7. Zhao L, Wang Y, Wang Z, Xu Z, Zhang Q, Yin M. Effects of dietary resveratrol on excess-iron-induced bone loss via antioxidative character. J Nutr Biochem. 2015;26:1174-82.

8. Han D-W, Park YH, Kim JK, Jung TG, Lee KY, Hyon SH, et al. Long-term preservation of human saphenous vein by green tea polyphenol under physiological conditions. Tissue Eng. 2005;11:1054-64.

9. Baranowska M, Koziara Z, Suliborska K, Chrzanowski W, Wormstone M, Namieśnik J, et al. Interactions between polyphenolic antioxidants quercetin and naringenin dictate the distinctive redox-related chemical and biological behaviour of their mixtures. Sci Rep. 2021;11:12282.

10. Shavandi A, Bekhit AE-DA, Saeedi P, Izadifar Z, Bekhit AA, Khademhosseini A Polyphenol uses in biomaterials engineering. Biomaterials. 2018;167:91-106. https://doi.org/10.1016/j.biomaterials.2018.03.018.

11. Kowalski R, Gonzalez E. de Mejia. Phenolic composition, antioxidant capacity and physical characterization of ten black-currant (Ribes nigrum) cultivars, their juices, and the inhibition of type 2 diabetes and inflammation biochemical markers. Food Chem. 2021;359:129889.

12. Đudarić L, Fužinac-Smojver A, Muhvić D, Giacometti J. The role of polyphenols on bone metabolism in osteoporosis. Food Res Int. 2015;77: 290-8.

13. Torre E, Iviglia G, Cassinelli C, Morra M. Potentials of polyphenols in boneimplant devices; 2018. https://doi.org/10.5772/intechopen.76319.

14. Gu Q, Cai Y, Huang C, Shi Q, Yang H. Curcumin increases rat mesenchymal stem cell osteoblast differentiation but inhibits adipocyte differentiation. Pharm Mag. 2012;8:202-8.

15. Bharti AC, Takada Y, Aggarwal BB. Curcumin (diferuloylmethane) inhibits receptor activator of NF-kappa B ligand-induced NF-kappa B activation in osteoclast precursors and suppresses osteoclastogenesis. J Immunol. 2004;172:5940-7.

16. Lee SK, Lorenzo J. Cytokines regulating osteoclast formation and function. Curr Opin Rheumatol. 2006;18:411-8.

17. Jagger CJ, Lean JM, Davies JT, Chambers TJ. Tumor necrosis factor-alpha mediates osteopenia caused by depletion of antioxidants. Endocrinology. 2005; 146:113-8

18. Ramakrishna H, Li T, He T, Temple J, King MW, Spagnoli A. Tissue engineering a tendon-bone junction with biodegradable braided scaffolds. Biomater Res. 2019;23:11.

19. Sheikh Z, Hamdan N, Ikeda Y, Grynpas M, Ganss B, Glogauer M. Natural graft tissues and synthetic biomaterials for periodontal and alveolar bone reconstructive applications: a review. Biomater Res. 2017;21:9.

20. Kim MH, Kim BS, Lee J, Cho D, Kwon OH, Park WH. Silk fibroin/ hydroxyapatite composite hydrogel induced by gamma-ray irradiation for bone tissue engineering. Biomater Res. 2017;21:12

21. Jeong J, Kim JH, Shim JH, Hwang NS, Heo CY. Bioactive calcium phosphate materials and applications in bone regeneration. Biomater Res. 2019;23:4.

22. Berton F, Porrelli D, Di Lenarda R, Turco G. A critical review on the production of electrospun nanofibres for guided bone regeneration in ora surgery. Nanomaterials. 2019;10:16.

23. Lee J, Lee S, Kim SM, Shin H. Size-controlled human adipose-derived stem cell spheroids hybridized with single-segmented nanofibers and their effect on viability and stem cell differentiation. Biomater Res. 2021;25:14.

24. Arampatzis AS, Kontogiannopoulos KN, Theodoridis K, Aggelidou E, Rat A, Willems $A$, et al. Electrospun wound dressings containing bioactive natural products: physico-chemical characterization and biological assessment. Biomater Res. 2021;25:23.

25. Khoshbakht S, Asghari-Sana F, Fathi-Azarbayjani A, Sharifi Y. Fabrication and characterization of tretinoin-loaded nanofiber for topical skin delivery. Biomater Res. 2020;24:8.

26. Mao Y, Zhao Y, Guan J, Guan J, Ye T, Chen Y, et al. Electrospun fibers: An innovative delivery method for the treatment of bone diseases. Exp Opin Drug Deliv. 2020;17:993-1005.

27. Boobalan G, Imran PK, Manoharan C, Nagarajan S. Fabrication of highly fluorescent perylene bisimide nanofibers through interfacial self-assembly. J Colloid Interface Sci. 2013;393:377-83.
28. Rollings D-aE, Veinot JGC. Polysiloxane nanofibers via surface initiated polymerization of vapor phase reagents: a mechanism of formation and variable wettability of fiber-bearing substrates. Langmuir. 2008;24:13653-62.

29. Jeon S, Karkhanechi H, Fang L-F, Cheng L, Ono T, Nakamura R, et al. Novel preparation and fundamental characterization of polyamide 6 selfsupporting hollow fiber membranes via thermally induced phase separation (TIPS). J Memb Sci. 2018;546:1-14.

30. Xu C, Inai R, Kotaki M, Ramakrishna S. Electrospun nanofiber fabrication as synthetic extracellular matrix and its potential for vascular tissue engineering. Tissue Eng. 2004;10:1160-8.

31. Nemati S, Kim S-J, Shin YM, Shin H. Current progress in application of polymeric nanofibers to tissue engineering. Nano Converg. 2019;6:36.

32. Doshi J, Reneker DH. Electrospinning process and applications of electrospun fibers. J Electrost. 1995;35:151-60.

33. Khorshidi S, Solouk A, Mirzadeh H, Mazinani S, Lagaron JM, Sharifi S, et al. A review of key challenges of electrospun scaffolds for tissue-engineering applications. J Tissue Eng Regen Med. 2016:10:715-38.

34. Shin YC, Yang WJ, Lee JH, Oh JW, Kim TW, Park JC, et al. PLGA nanofiber membranes loaded with epigallocatechin-3-O-gallate are beneficial to prevention of postsurgical adhesions. Int J Nanomedicine. 2014;9:4067-78.

35. Zarei F, Soleimaninejad M. Role of growth factors and biomaterials in wound healing. Artif Cells Nanomed Biotechnol. 2018;46:906-11.

36. Grazul-Bilska AT, Johnson ML, Bilski JJ, Redmer DA, Reynolds LP, Abdullah A, et al. Wound healing: the role of growth factors. Drugs Today. 2003;39:787800.

37. Córdoba A, Satué M, Gómez-Florit M, Hierro-Oliva M, Petzold C, Lyngstadaas $\mathrm{SP}$, et al. Flavonoid-modified surfaces: multifunctional bioactive biomaterials with osteopromotive, anti-inflammatory, and anti-fibrotic potential. Adv Healthc Mater. 2015:4:540-9.

38. Bottino MC, Kamocki $K$, Yassen GH, Platt JA, Vail MM, Ehrlich $Y$, et al. Bioactive nanofibrous scaffolds for regenerative endodontics. J Dent Res. 2013:92:963-9.

39. Liu Z, Ramakrishna S, Liu X. Electrospinning and emerging healthcare and medicine possibilities. APL Bioeng. 2020;4:030901.

40. Ranjbar-Mohammadi M, Rabbani S, Bahrami SH, Joghataei MT, Moayer F. Antibacterial performance and in vivo diabetic wound healing of curcumin loaded gum tragacanth/poly( $\varepsilon$-caprolactone) electrospun nanofibers. Mater Sci Eng C. 2016;69:1183-91.

41. He P, Zhong Q, Ge Y, Guo Z, Tian J, Zhou Y, et al. Dual drug loaded coaxial electrospun PLGA/PVP fiber for guided tissue regeneration under control of infection. Mater Sci Eng C. 2018;90:549-56.

42. Guo Q, Liu C, Li J, Zhu C, Yang H, Li B. Gene expression modulation in TGF$\beta 3$-mediated rabbit bone marrow stem cells using electrospun scaffolds of various stiffness. J Cell Mol Med. 2015;19:1582-92.

43. Lyu H-Z, Lee $J H$. The efficacy of rhBMP-2 loaded hydrogel composite on bone formation around dental implants in mandible bone defects of minipigs. Biomater Res. 2020;24:5.

44. Abbasi N, Lee RSB, Ivanovski S, Love RM, Hamlet S. In vivo bone regeneration assessment of offset and gradient melt electrowritten (MEW) PCL scaffolds. Biomater Res. 2020;24:17.

45. Majidinia M, Sadeghpour A, Yousefi B. The roles of signaling pathways in bone repair and regeneration. J Cell Physiol. 2018;233:2937-48.

46. Lee DK, Ki M-R, Kim EH, Park C-J, Ryu JJ, Jang HS, et al. Biosilicated collagen/ $\beta$-tricalcium phosphate composites as a BMP-2-delivering bone-graft substitute for accelerated craniofacial bone regeneration. Biomater Res. 2021;25:13.

47. Tatsuyama K, Maezawa Y, Baba H, Imamura Y, Fukuda M. Expression of various growth factors for cell proliferation and cytodifferentiation during fracture repair of bone. Euro J Histochem. 2000;44:269-78.

48. Behzadi S, Luther GA, Harris MB, Farokhzad OC, Mahmoudi M. Nanomedicine for safe healing of bone trauma: opportunities and challenges. Biomaterials. 2017;146:168-82.

49. Raggatt $\sqcup$, Partridge NC. Cellular and molecular mechanisms of bone remodeling. J Biol Chem. 2010;285:25103-8.

50. Thitiset T, Damrongsakkul S, Yodmuang S, Leeanansaksiri W, Apinun J, Honsawek S. A novel gelatin/chitooligosaccharide/demineralized bone matrix composite scaffold and periosteum-derived mesenchymal stem cells for bone tissue engineering. Biomater Res. $2021 ; 25: 19$

51. Teitelbaum SL. Osteoclasts: what do they do and how do they do it? Amer J Pathol. 2007;170:427-35. 
52. Plotkin LI, Bruzzaniti A. Molecular signaling in bone cells: regulation of cell differentiation and survival. Adv Protein Chem Struct Biol. 2019;116:237-81.

53. Sikavitsas VI, Temenoff JS, Mikos AG. Biomaterials and bone mechanotransduction. Biomaterials. 2001:22:2581-93.

54. Ansari M. Bone tissue regeneration: biology, strategies and interface studies. Prog Biomater. 2019;8:223-37.

55. Cho TJ, Gerstenfeld LC, Einhorn TA. Differential temporal expression of members of the transforming growth factor beta superfamily during murine fracture healing. J Bone Miner Res. 2002;17:513-20.

56. Rundle $\mathrm{CH}$, Wang $\mathrm{H}, \mathrm{Yu} \mathrm{H}$, Chadwick RB, Davis El, Wergedal JE, et al. Microarray analysis of gene expression during the inflammation and endochondral bone formation stages of rat femur fracture repair. Bone. 2006;38:521-9

57. Wang X, Wang Y, Gou W, Lu Q, Peng J, Lu S. Role of mesenchymal stem cells in bone regeneration and fracture repair: a review. Int Orthop. 2013;37: 2491-8.

58. Kular J, Tickner J, Chim SM, Xu J. An overview of the regulation of bone remodelling at the cellular level. Clin Biochem. 2012;45:863-73.

59. Ahmed MF, El-Sayed AK, Chen H, Zhao R, Yusuf MS, Zuo Q, et al. Comparison between curcumin and all-trans retinoic acid in the osteogenic differentiation of mouse bone marrow mesenchymal stem cells. Exp Ther Med. 2019;17:4154-66.

60. Safali S, Aydin BK, Nayman A, Ugurluoglu C. Effect of curcumin on bone healing: An experimental study in a rat model of femur fracture. Injury. 2019;50:1915-20.

61. Vester H, Holzer N, Neumaier M, Lilianna S, Nüssler AK, Seeliger C. Green tea extract (GTE) improves differentiation in human osteoblasts during oxidative stress. J Inflamm. 2014;11:15.

62. Shen CL, Yeh JK, Stoecker BJ, Chyu MC, Wang JS. Green tea polyphenols mitigate deterioration of bone microarchitecture in middle-aged female rats. Bone. 2009;44:684-90.

63. Iviglia G, Torre E, Cassinelli C, Morra M. Functionalization with a polyphenolrich pomace extract empowers a ceramic bone filler with in vitro antioxidant, anti-inflammatory, and pro-osteogenic properties. J Funct Biomater. 2021;12:31.

64. Fan J, Li J, Fan Q. Naringin promotes differentiation of bone marrow stem cells into osteoblasts by upregulating the ex-pression levels of microRNA20a and downregulating the expression levels of PPARy. Mol Med Rep. 2015;12:4759-65.

65. Zhang X, Zhou C, Zha X, Xu Z, Li L, Liu Y, et al. Apigenin promotes osteogenic differentiation of human mesenchymal stem cells through JNK and p38 MAPK pathways. Mol Cell Biochem. 2015;407:41-50.

66. Zhao J, Ohba S, Komiyama Y, Shinkai M, Chung UI, Nagamune T. Icariin: a potential osteoinductive compound for bone tissue engineering. Tissue Eng A. $2010 ; 16: 233-43$.

67. Xin M, Yang Y, Zhang D, Wang J, Chen S, Zhou D. Attenuation of hind-limb suspension-induced bone loss by curcumin is associated with reduced oxidative stress and increased vitamin D receptor expression. Osteoporos Int. 2015;26:2665-76

68. Lone J, Choi JH, Kim SW, Yun JW. Curcumin induces brown fat-like phenotype in 3T3-L1 and primary white adipocytes. J Nutr Biochem. 2016; 27:193-202.

69. Kim WK, Ke K, Sul OJ, Kim HJ, Kim SH, Lee MH, et al. Curcumin protects against ovariectomy-induced bone loss and decreases osteoclastogenesis. J Cell Biochem. 2011;112:3159-66.

70. Yang MW, Wang TH, Yan PP, Chu LW, Yu J, Gao ZD, et al. Curcumin improves bone microarchitecture and enhances mineral density in APP/PS1 transgenic mice. Phytomedicine. 2011;18:205-13.

71. Zhou C, Lin Y. Osteogenic differentiation of adipose-derived stem cells promoted by quercetin. Cell Prolif. 2014;47:124-32

72. Kim IR, Kim SE, Baek HS, Kim BJ, Kim CH, Chung IK, et al. The role of kaempferol-induced au-tophagy on differentiation and mineralization of osteoblastic MC3T3-E1 cells. BMC Complement Altern Med. 2016;16:333.

73. Mah YJ, Song JS, Kim SO, Lee JH, Jeon M, Jung UW, et al. The effect of epigallocate-chin-3-gallate (EGCG) on human alveolar bone cells both in vitro and in vivo. Arch Oral Biol. 2014;59:539-49.

74. Wong RW, Rabie AB. Effect of quercetin on bone formation. J Orthop Res. 2008:26:1061-6.

75. Hämäläinen M, Nieminen R, Vuorela P, Heinonen M, Moilanen E. Antiinflammatory effects of flavonoids: genistein, kaempferol, quercetin, and daidzein inhibit STAT-1 and NF-kappaB activations, whereas flavone, isorhamnetin, naringenin, and pelargonidin inhibit only NF-kappaB activation along with their inhibitory effect on iNOS expression and NO production in activated macrophages. Mediat Inflamm. 2007;2007:45673.

76. Li N, Jiang Y, Wooley PH, Xu Z, Yang SY. Naringin promotes osteoblast differentiation and effectively reverses ovariectomy-associated osteoporosis. J Orthop Sci. 2013;18:478-85.

77. Rithidech KN, Tungjai M, Reungpatthanaphong P, Honikel L, Simon SR. Attenuation of oxidative damage and in-flammatory responses by apigenin given to mice after irradiation. Mutat Res. 2012;749:29-38.

78. Greenblatt MB, Shim JH, Zou W, Sitara D, Schweitzer M, Hu D, et al. The p38 MAPK pathway is essential for skeletogenesis and bone homeostasis in mice. J Clin Invest. 2010;120:2457-73.

79. Ma Z, Wang R, Qiu M. Study of morphologic effects of 4 Chinese herbs by bone histomorphometry in ovariectomized rats. Zhonghua Fu Chan Ke Za Zhi. 1999:34:82-5.

80. Yu S, Chen K, Li S, Zhang K. In vitro and in vivo studies of the effect of a Chinese herb medicine on osteoclastic bone resorption. Chin J Dent Res. 1999;2:7-11.

81. Asghari F, Samiei M, Adibkia K, Akbarzadeh A, Davaran S. Biodegradable and biocompatible polymers for tissue engineering application: a review. Artif Cells Nanomed Biotechnol. 2017:45:185-92.

82. BaoLin G, Ma PX. Synthetic biodegradable functional polymers for tissue engineering: a brief review. Sci China Chem. 2014;57:490-500.

83. Song R, Murphy M, Li C, Ting K, Soo C, Zheng Z. Current development of biodegradable polymeric materials for biomedical applications. Drug Des Devel Ther. 2018;12:3117-45.

84. Ogueri KS, Laurencin CT. Nanofiber technology for regenerative engineering. ACS Nano. 2020;14:9347-63.

85. Ahmadi S, Rabiee N, Bagherzadeh M, Elmi F, Fatahi Y, Farjadian F, et al. Stimulus-responsive sequential release systems for drug and gene delivery. Nano Today. 2020;34:100914

86. Ishihara M, Kishimoto S, Nakamura S, Sato Y, Hattori H. Polyelectrolyte complexes of natural polymers and their biomedical applications. Polymers. 2019;11:672.

87. Limo MJ, Sola-Rabada A, Boix E, Thota V, Westcott ZC, Puddu V, et al. Interactions between metal oxides and biomolecules: from fundamental understanding to applications. Chem Rev. 2018;118:11118-93.

88. Amani $H$, Arzaghi H, Bayandori M, Dezfuli AS, Pazoki-Toroudi H, Shafiee A, et al. Controlling cell behavior through the design of biomaterial surfaces: a focus on surface modification techniques. Adv Mater Interfaces. 2019;6:1900572.

89. Tallawi M, Rosellini E, Barbani N, Cascone MG, Rai R, Saint-Pierre G, et al. Strategies for the chemical and biological functionalization of scaffolds for cardiac tissue engineering: a review. J R Soc Interface. 2015;12:20150254.

90. Lin X, Patil S, Gao YG, Qian A. The bone extracellular matrix in bone formation and regeneration. Front Pharmacol. 2020;11:757.

91. Klamer $S$, Voermans $C$. The role of novel and known extracellular matrix and adhesion molecules in the homeostatic and regenerative bone marrow microenvironment. Cell Adhes Migr. 2014;8:563-77.

92. Fraioli R, Rechenmacher F, Neubauer S, Manero JM, Gil J, Kessler H, et al. Mimicking bone extracellular matrix: integrin-binding peptidomimetics enhance osteoblast-like cells adhesion, proliferation, and differentiation on titanium. Colloids Surf B. 2015;128:191-200.

93. Li X, Liu W, Sun L, Fan Y, Feng Q. The application of inorganic nanomaterials in bone tissue engineering. J Biomater Tissue Eng. 2014;4: 994-1003.

94. Jain S, Meka SR, Chatterjee K. Curcumin eluting nanofibers augment osteogenesis toward phytochemical based bone tissue engineering. Biomed Mater. 2016;11:055007.

95. Sedghi R, Sayyari N, Shaabani A, Niknejad H, Tayebi T. Novel biocompatible zinc-curcumin loaded coaxial nanofibers for bone tissue engineering application. Polymer. 2018;142:244-55.

96. Lee JS, Lee JS, Lee MS, An S, Yang K, Lee K, et al. Plant flavonoid-mediated multifunctional surface modification chemistry: Catechin coating for enhanced osteogenesis of human stem cells. Chem Mater. 2017:29:4375-84.

97. Jeong HG, Han YS, Jung KH, Kim YJ. Poly(vinylidene fluoride) composite nanofibers containing polyhedral oligomeric silsesquioxane-epigallocatechin gallate conjugate for bone tissue regeneration. Nanomaterials. 2019;9:184.

98. Preeth DR, Saravanan S, Shairam M, Selvakumar N, Raja IS, Dhanasekaran A, et al. Bioactive zinc(II) complex incorporated PCL/gelatin electrospun nanofiber enhanced bone tissue regeneration. Eur J Pharm Sci. 2021;160: 105768 . 
99. Riccitiello F, De Luise A, Conte R, D'Aniello S, Vittoria V, Di Salle A, et al. Effect of resveratrol release kinetic from electrospun nanofibers on osteoblast and osteoclast differentiation. Eur Polym J. 2018;99:289-97.

100. Gong M, Huang C, Huang Y, Li G, Chi C, Ye J, et al. Core-sheath micro/nano fiber membrane with antibacterial and osteogenic dual functions as biomimetic artificial periosteum for bone regeneration applications. Nanomed Nanotech Biol Med. 2019;17:124-36.

101. Gong M, Chi C, Ye J, Liao M, Xie W, Wu C, et al. Icariin-loaded electrospun $\mathrm{PCL} /$ gelatin nanofiber membrane as potential artificial periosteum. Colloids Surf B. 2018;170:201-9.

102. Dhand C, Ong ST, Dwivedi N, Diaz SM, Venugopal JR, Navaneethan B, et al. Bio-inspired in situ crosslinking and mineralization of electrospun collagen scaffolds for bone tissue engineering. Biomaterials. 2016;104:323-38.

103. Tominari T, Matsumoto C, Watanabe K, Hirata M, Grundler FM, Miyaura C, et al. Epigallocatechin gallate (EGCG) suppresses lipopolysaccharide-induced inflammatory bone resorption, and protects against alveolar bone loss in mice. FEBS Open Bio. 2015:5:522-7.

104. Chu C, Deng J, Hou Y, Xiang L, Wu Y, Qu Y, et al. Application of PEG and EGCG modified collagen-base membrane to promote osteoblasts proliferation. Mater Sci Eng C. 2017;76:31-6.

105. Bradamante S, Barenghi L, Villa A. Cardiovascular protective effects of resveratrol. Cardiovasc Drug Rev. 2004;22:169-88.

106. de la Lastra CA, Villegas I. Resveratrol as an anti-inflammatory and anti-aging agent: mechanisms and clinical implications. Mol Nutr Food Res. 2005;49: 405-30.

107. He X, Andersson G, Lindgren U, Li Y. Resveratrol prevents RANKL-induced osteoclast differentiation of murine osteoclast progenitor RAW 264.7 cells through inhibition of ROS production. Biochem Biophys Res Commun. 2010;401:356-62.

108. Horváth A, Mardas N, Mezzomo LA, Needleman IG, Donos N. Alveolar ridge preservation. A systematic review. Clin Oral Investig. 2013;17:341-63.

109. Tou JC. Resveratrol supplementation affects bone acquisition and osteoporosis: pre-clinical evidence toward translational diet therapy. Biochim Biophys Acta. 2015;1852:1186-94.

110. Chimento A, De Amicis F, Sirianni R, Sinicropi MS, Puoci F, Casaburi I, et al. Progress to improve oral bioavailability and beneficial effects of resveratrol. Int J Mol Sci. 2019;20:1381.

\section{Publisher's Note}

Springer Nature remains neutral with regard to jurisdictional claims in published maps and institutional affiliations.

Ready to submit your research? Choose BMC and benefit from:

- fast, convenient online submission

- thorough peer review by experienced researchers in your field

- rapid publication on acceptance

- support for research data, including large and complex data types

- gold Open Access which fosters wider collaboration and increased citations

- maximum visibility for your research: over $100 \mathrm{M}$ website views per year

At BMC, research is always in progress.

Learn more biomedcentral.com/submissions 